\title{
Living up to their name: Profamilia takes on gender-based violence
}

Claudia Garcia-Moreno

Rachel E. Goldberg

Follow this and additional works at: https://knowledgecommons.popcouncil.org/departments_sbsr-pgy

Part of the Community-Based Research Commons, Demography, Population, and Ecology Commons, Domestic and Intimate Partner Violence Commons, Family, Life Course, and Society Commons, Health Policy Commons, International Public Health Commons, and the Women's Health Commons How does access to this work benefit you? Let us know!

\section{Recommended Citation}

Garcia-Moreno, Claudia and Rachel E. Goldberg. 2006. "Living up to their name: Profamilia takes on gender-based violence," Quality/Calidad/Qualité no. 18. New York: Population Council. 
Living Up to Their Name:

Profamilia Takes on

Gender-based Violence

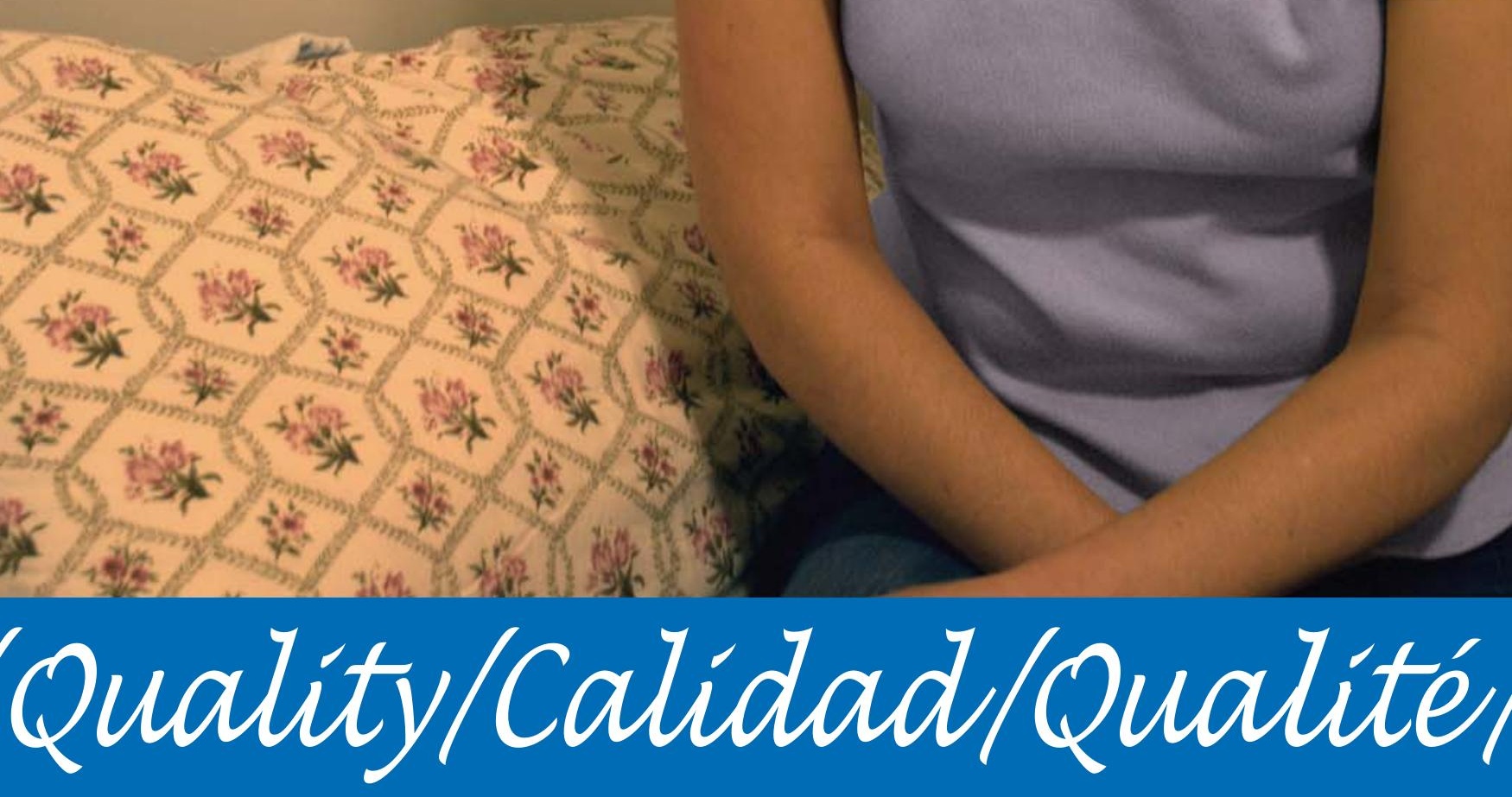




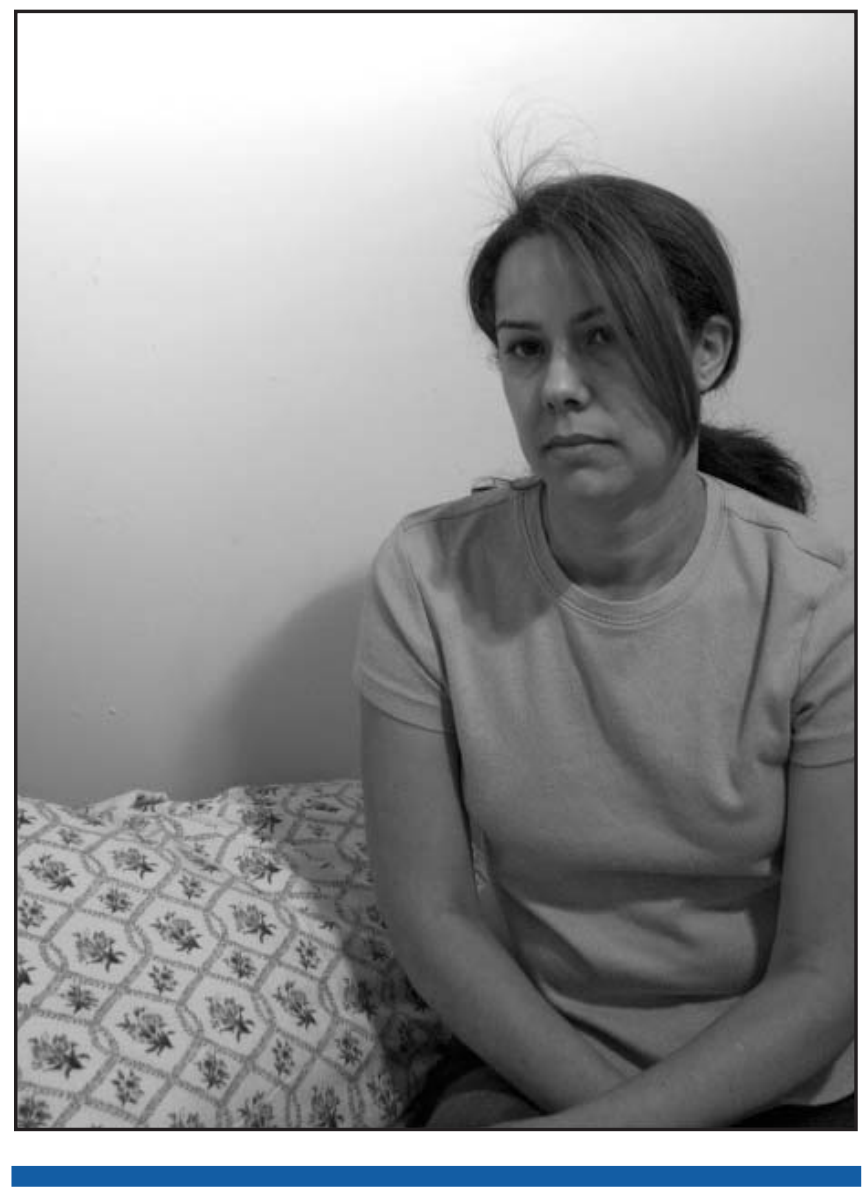

Living Up to Their Name: Profamilia Takes on Gender-based Violence 
Quality/Calidad/Qualité, a publication of the Population Council, presents case studies of high-quality, innovative programs in sexual and reproductive health. $Q / C / Q$ specifically documents educational and clinic-based programs that are making strides in one or more of the following ways: (1) addressing the central importance of gender dynamics in shaping sexual and reproductive health outcomes; (2) improving the quality of care of clinic-based services; and (3) reaching disadvantaged and underserved groups. With rare exceptions, featured programs are operating in developing countries.

$Q / C / Q$ case studies_-selected by an expert advisory group-are offered not as models for replication, but as examples for learning. They demonstrate a responsiveness to broader social and economic transformations; they highlight inventive and affordable ways to respond to clients' needs; and they reflect the self-critical and flexible attitude required for learning from program experiences and research evidence. Although they are written as practical toolsin accessible style with carefully selected detail-they also serve to inspire program leaders and policymakers to enable clients to become more effective guardians of their sexual and reproductive health, and by doing so contribute fundamentally to the achievement of such broader aims as the Millennium Development Goals.

\section{Production Staff}

Editor: Debbie Rogow

\section{Editorial and production coordinator: Michelle Skaer}

Copyeditor: Karen Tweedy-Holmes

Designer: Mike Vosika

Translators: Charo Quesada (Spanish) and Genevieve Haines (French)

$\begin{array}{ll}\text { Advis ory Com mittee } \\ \text { Delia Barcelona } & \text { Laura Laski } \\ \text { Gary Barker } & \text { Ann Leonard } \\ \text { Carmen Barroso } & \text { Ann McCauley } \\ \text { Judith Bruce } & \text { Liz McGrory } \\ \text { Batya Elul } & \text { Manisha Mehta } \\ \text { Susana Galdos } & \text { Suellen Miller } \\ \text { Françoise Girard } & \text { Saumya Ramarao } \\ \text { Nicole Haberland } & \text { Ann Starrs } \\ \text { Katherine Kurz } & \text { Cynthia Steele }\end{array}$

\section{(2) Population Council}

Publication of this edition of Quality/Calidad/Qualité is made possible by support provided by the Ford Foundation and by the Gender, Family, and Development Program of the Population Council. Statements made and views expressed in this publication are solely the responsibility of the authors and not of any organization providing support for $Q / C / Q$.

The Population Council is an international, nonprofit, nongovernmental organization that seeks to improve the well-being and reproductive health of current and future generations around the world and to help achieve a humane, equitable, and sustainable balance between people and resources. The Council conducts biomedical, social science, and public health research and helps build research capacities in developing countries. Established in 1952, the Council is governed by an international board of trustees. Its New York headquarters supports a global network of regional and country offices.

Population Council, One Dag Hammarskjold Plaza, New York, NY 10017 USA

tel: (212) 339-0500 fax: (212) 755-6052 e-mail: qcq@popcouncil.org http://www.popcouncil.org

Cover photograph by Karen Tweedy-Holmes. Subject of photographs on front cover and page 28 is a model and is not associated with either the Profamilia program or with the Population Council.

Issue No. 18 ISSN: 1097-8194

(C) 2006 The Population Council, Inc.

Any part of this publication may be copied or adapted to meet local needs without permission from the Population Council, provided that the parts copied are distributed free or at cost (not for profit) and that the source is identified. The Population Council would appreciate receiving a copy of any materials in which the text is used. 


\title{
Introduction
}

\author{
by Claudia García-Moreno
}

Women activists have long challenged communities and policymakers to recognize violence against girls and women as a critical social problem. Largely as a result of their persistent research and organizing efforts, such violence is now more widely understood as an abuse of women's basic human rights and, more recently, as a global public health concern. In the past two decades, the term "gender-based violence" has also come into use, reflecting an understanding of the particular role that women's and girls' unequal status plays in perpetuating, and even condoning, this abuse. During the same period, the urgent need to address the problem has been underscored in a series of international agreements and declarations.' Currently, combating such violence is one of the seven key strategies for the achievement of women's empowerment and gender equality, which is one of the Millennium Development Goals (UN 2005). Nevertheless, these policy advances have not always translated into budgetary allocations and concerted action; the need exists for greater political will and technical know-how to implement effective strategies to prevent gender-based violence and provide services and programs to address its consequences.

\section{Nature and Magnitude of the Problem}

Research-particularly that conducted in developing countries-has contributed to a growing awareness among governments and policymakers about the nature and magnitude of violence against women. Such violence takes many forms-physical, sexual, and emotional; it also refers to sex trafficking and to harmful practices. Violence takes place in many settings: in the home, in the community, or in custodial situations such as prisons; women and girls may be particularly exposed to sexual abuse in situations of armed conflict and population displacement. Family members, acquaintances, strangers, or agents of the state may all perpetrate violence, but data on prevalence have shown that most often women experience violence at the hands of their own intimate male partners.

One of the most notable aspects of violence prevalence rates is their variation; violence against females persists (and is condoned) almost everywhere, but to very different degrees. An early review of more than 50 populationbased studies carried out in 35 countries found that the proportion of women who reported experiencing past abuse from an intimate partner ranged from 10 to 52 percent for physical abuse

\footnotetext{
1 These include, for example, the International Conference on Human Rights (Vienna, 1993), the Declaration on the Elimination of Violence against Women (UN, 1993), the International Conference on Population and Development (Cairo, 1994), the Fourth International Conference on Women (Beijing, 1995), and the World Health Assembly (Geneva, 1996).
} 
and between 10 and 30 percent for sexual abuse (Heise et al. 1999). Although these studies were not comparable, ${ }^{2}$ a more recent World Health Organization (WHO) ten-country study using standardized methodology documented a similar pattern (Garcia-Moreno et al. 2005). ${ }^{3}$ This study found that the proportion of women reporting experience of sexual or physical violence or both from a partner ranged between 15 to 71 percent, with most sites falling between 29 and 62 percent $^{4}$ (Garcia-Moreno et al. 2005).

The prevalence of violence is influenced by a web of interrelated factors. In the WHO study, rates of intimate partner abuse tended to be higher in more rural settings (possibly a proxy for conservative norms) and in developing countries. ${ }^{5}$ Although men across the economic spectrum perpetrate domestic violence, rates appear to be higher in resource-poor settings. Such violence may become more common when men feel powerless. Women in such settings also may have fewer options for leaving an abusive relationship. Further analysis of the range of risk and protective factors at individual, family, community, social, and cultural levels is needed to better understand differences in prevalence.

\section{Health Consequences}

Gender-based violence is associated with a wide range of physical and mental health problems that affect not only the victim but also her children. It also has an impact on other aspects of women's lives, such as their ability to work, and ultimately it results in serious costs to the whole of society (Heise and Garcia-Moreno 2002). Women who suffer such violence are more likely to experience depression and anxiety disorders, injuries and resulting disabilities, and chronic pain syndromes. They are also vulnerable to a range of sexual and reproductive health outcomes. For example, forced sex and fear of violence both undermine a woman's or girl's ability to negotiate condom or contraceptive use; indeed, women who experience violence are at greater risk than other women of acquiring HIV infection and experiencing unwanted pregnancy (Campbell 2002; Jewkes et al. 2002). Violence against pregnant women is another common problem and is associated with a variety of poor outcomes, including miscarriage, stillbirth, preterm labor, and low birth weight (Campbell 2002). In developed countries, gender-based violence during pregnancy is an important cause of maternal mortality (Campbell et al. 2004). Researchers also are beginning to document the contribution of genderbased violence to overall female mortality, both from homicide and from suicide among the victims of violence.

\section{What Can Sexual and Reproductive Health Providers Do?}

Violence remains a shameful and stigmatizing matter for many women. The aforementioned WHO study found that between one-fifth to two-thirds of the women surveyed had never spoken to anyone about their experience of abuse before the interview. Similarly, the results

\footnotetext{
${ }^{2}$ The authors note that comparisons between these studies are difficult because of methodological differences (for example, the sample of women studied, the way questions were asked, or the time frame used).

${ }^{3}$ The survey sample for the WHO study was more than 24,000 women in Bangladesh, Brazil, Ethiopia, Japan, Namibia, Peru, Samoa, Serbia and Montenegro, Tanzania, and Thailand.

${ }^{4}$ The specific rate for sexual violence perpetuated by partners generally fell between 10 and 50 percent, whereas the specific rate for physical violence perpetrated by partners ranged from 13 to 61 percent.

${ }^{5}$ This finding holds particularly true for rates of violence during the 12 months prior to reporting.
} 
showed that few women sought help from formal services, but when they did, typically they turned to health and police personnel (Garcia-Moreno et al. 2005).

Women's health services (including antenatal, family planning, and postabortion care and treatment for sexually transmitted infections) are particularly well placed for identifying women in abusive relationships and for offering them referrals or support services. However, providers need to be aware of and to challenge the socially approved norms that underlie gender-based violence; indeed, these same norms lead to myriad other sexual and reproductive health problems. Involving men and working with young people are also important to such efforts (Barker 2003).

As the example of Profamilia shows, reproductive health providers who are sensitized and trained to recognize and respond to violence are able to recognize ways of providing better care, support services, and referrals. In settings where resources are limited and referral is not possible, health-care staff should at least be aware of the problem, provide information about legal and counseling options, and emphasize that such violence is a widespread problem and that it is wrong. Ensuring confidentiality and women's safety should be paramount.

Profamilia's experience also highlights that a decision to address violence must involve the whole institution, involving sensitization of all staff, including receptionists and security staff; modifying the physical space of clinics for privacy and confidentiality; changing patient flows; and developing protocols, an information system, and a strong network for referral. Another important feature of Profamilia's work is that direct service provision is linked to prevention: The organization is deeply engaged in advocacy, working in multisectoral alliances (including the criminal justice system and the media) for change in the law and in social norms. Investment of resources, both human and financial, and a commitment from the top level of the institution are clearly important to the success of this effort.

Ultimately, as the name Profamilia suggests, addressing the problem of intimate partner violence has the potential to benefit not only the individual woman, but her whole family. Examples of such successful services are useful and merit analysis of their outcomes in terms of cost and applicability to the public sector. With such efforts, we can begin to reverse the epidemic of gender-based violence affecting millions of women and girls around the world.

\section{References}

Barker, Gary. 2003. "Introduction." In "My Father Didn't Think This Way": Nigerian Boys Contemplate Gender Equality. New York: Population Council.

Campbell, J.C. 2002. "Health consequences of intimate partner violence." Lancet 359(9,314): 1,331-1,336.

Campbell, J.C., Claudia García-Moreno, and P. Sharps. 2004. "Abuse during pregnancy in industrialized and developing countries." Violence Against Women 10(7): 770-789.

García-Moreno, Claudia et al. 2005. The WHO Multi-country Study on Women's Health and Domestic Violence Against Women. Initial Results on Prevalence, Health Outcomes and Women's Responses. Geneva: World Health Organization.

Heise, Lori, Mary Ellsberg, and M. Gottemuller. 1999. Ending Violence Against Women. Baltimore: Johns Hopkins University Press.

Heise, Lori and Claudia García-Moreno. 2002. "Intimate partner violence." In World Report on Violence and Health. Eds. E. Krug et al. Geneva: World Health Organization.

Jewkes, Rachel, P. Sen, and Claudia GarcíaMoreno. 2002. "Sexual violence." In World Report on Violence and Health. Eds. E. Krug et al. Geneva: World Health Organization.

United Nations. 2005. Resolution adopted by the General Assembly 60/1. World Summit Outcome. New York: United Nations. 


\section{The Dominican Republic at a Glance}

The Dominican Republic is the second-largest nation in area and population in the Caribbean islands. The country suffers from marked income inequality, and macroeconomic adjustments in recent decades actually reduced spending for education and health (PAHO 2001). The service sector has overtaken agricultural exports as the primary Dominican industries, resulting in massive migration from rural areas; approximately twothirds of Dominicans now reside in urban areas (UNFPA 2004). Emigration to other countries has been considerable; indeed, about one million Dominicans now live in the United States alone (CESDEM et al. 2003), and their remittances home constitute major contributions to Dominican family incomes.

Gender arrangements generally are typical of the region. Dominican girls tend to complete more years of secondary school than boys. For example, the secondary-school enrollment rate among females is 73 percent, compared with 60 percent among boys (UNFPA 2004). In comparison with their schooling, however, females fare poorly in the workforce. Although Dominican women are increasingly engaged in the workforce and currently head 28 percent of households (CESDEM et al. 2003), they are less likely than men to work for pay. Moreover, 24 percent of females are unemployed, compared with 9 percent of males (World Bank 2002).

The Dominican institution of marriage is a fragile one. Fifty percent of girls marry or enter into unions before the age of 19. Consensual union is far more common than formal marriage, however (CESDEM et al. 2003), although such unions leave women without legal rights to property or benefits upon separation from or death of a partner. Moreover, marital dissolution rates are high; by the time they reach their late 40s, more than one-fourth of ever-married women are separated or divorced (CESDEM et al. 2003). In addition to these changes, the Dominican fertility rate has fallen dramatically, from 4.3 children per woman in 1981 to 3.0 children per woman in 2002 (CONAPOFA 1987; CESDEM et al. 2003).

The Dominican Republic has one of the highest HIV-prevalence rates in Latin America and the Caribbean region; 2.5 percent of the population live with the virus. Approximately three-fourths of AIDS cases in the country are the result of heterosexual transmission (UNAIDS 2002a). As in other parts of the world, women of reproductive age constitute one of the populations with the most rapidly rising rates of new infection; indeed, HIV/AIDS is now the leading cause of death among Dominican women of reproductive age (UNAIDS 2003).

Women have made some gains at the level of public leadership. Recent modifications to the electoral law require that women constitute 33 percent of the candidates to congressional and local office; nevertheless, the proportion of women who serve as senators, deputy senators, deputy ministers, and mayors is below the regional average. Other forms of female participation in society have also increased considerably during the past few years. Women are active in the rising number of nongovernmental organizations (NGOs), particularly in the areas of health, women rights, domestic violence, participatory citizenship, and microfinance (World Bank 2002).

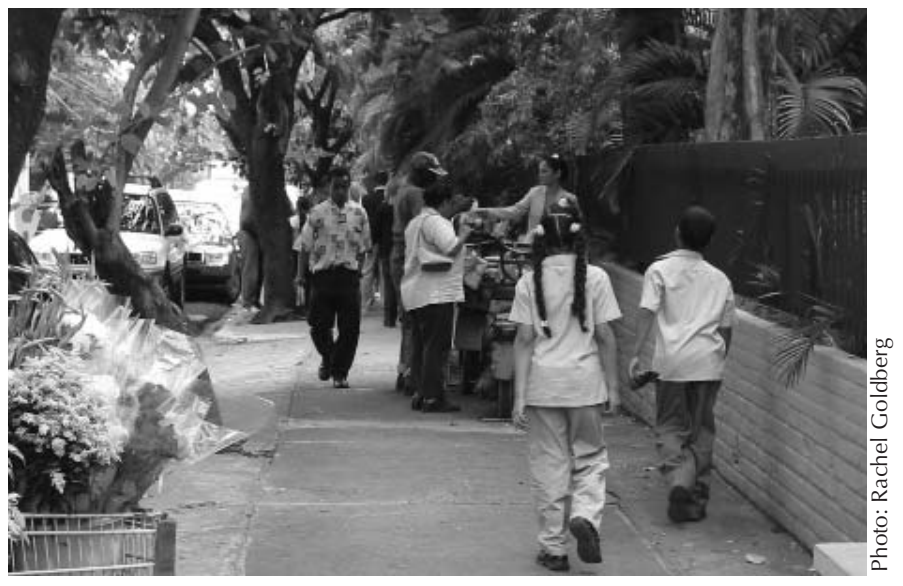

Dominican girls tend to complete more years of school than boys, but are ultimately less likely to work for pay. 


\title{
Living Up to Their Name: \\ Profamilia Takes on \\ Gender-based Violence
}

\author{
by Rachel Goldberg
}

I asked a woman whom I had been treating for a long time about whether she was experiencing violence. She said, "Caramba, I have wanted to talk with you about this for a long time, but I thought that you wouldn't be interested. I thought it was my problem, and that it wouldn't be something important to you."

It was like something out of a book.

—Frank Alvarez, Profamilia Clinic

In 2002, policymakers in the Dominican Republic had a wake-up call. For the first time, the national Demographic and Health Survey (DHS) had included questions about gender-based violence, and the results provided a disturbing picture. ${ }^{1}$ Nearly one in four women interviewed reported having ever experienced physical violence since the age of 15; 10 percent had experienced such violence in the last 12 months. Rates of violence were higher among the less-educated women surveyed, although women of all social strata reported abuse. ${ }^{2}$

The DHS findings echoed the pattern of gender-based violence in most settings. The primary perpetrators were intimate male partners, and violent behavior was often associated with use of alcohol. ${ }^{3}$ Women's experience of spousal vio- lence was closely correlated to their husbands' tendency to exhibit other controlling behaviors (Kishor and Johnson 2004). ${ }^{4}$ Often, the pattern of violence emerged early in a relationship. For example, among ever-married women who had experienced spousal abuse, 58 percent reported that the violence began within the first two years of the marriage or union (Kishor and Johnson 2004).

Twenty-one percent of Dominican women who reported experiencing spousal violence said they visited a health facility as a consequence of the resulting injuries (Kishor and Johnson 2004); often, however, these women do not disclose the source of their injuries even to their providers. Indeed, most victims of violence suffer in silence.

\footnotetext{
1 The Dominican Republic was among the first countries to incorporate a module on domestic violence into the DHS. In the 2002 DHS, among 23,384 women aged 15-49, 8,746 were asked questions about their experience of domestic violence.

2 A history of having experienced physical abuse was reported by nearly 27 percent of women with a primary-school education or less, by 22 percent of those with a secondary education, and by 18 percent of those with a college education.

${ }^{3}$ Among ever-married Dominican women whose husbands do not drink to excess, 5 percent reported having experienced spousal violence in the past year, compared with 34 percent among women whose husbands frequently come home drunk (Kishor and Johnson 2004). Although excessive drinking is associated with gender-based violence, this finding does not indicate that drinking alcohol causes this violence.

${ }^{4}$ The DHS questionnaire sought information on six controlling behaviors, namely: whether the respondent's husband is jealous or angry if she talks to other men; whether he frequently accuses her of being unfaithful; whether he does not permit her to meet her girlfriends; whether he limits her contacts with her family;
} 


\section{Profamilia}

Profamilia, a nongovernmental organization (NGO) and member association of the International Planned Parenthood Federation/Western Hemisphere Region (IPPF/WHR), was founded in 1966 as a family planning provider. Today the organization has a much broader mandate, with a range of reproductive health and other medical services. Profamilia's seven service sites include five urban clinics (one focused on adolescents) in three cities, one rural clinic, and one mental health center. In 2003, Profamilia provided 12,997 contraceptive services

We thought that we would have waiting rooms full of women.

But it wasn't like that. Women were very scared, and providers didn't refer them to us.

and 182,555 services for other sexual and reproductive health needs. Beyond clinical services, the organization sponsors social science and biomedical research and operates a national adolescent peer-educator program.

Magaly Caram has served as Executive Director of Profamilia since 1979. She had a longstanding interest in gender issues and, over the years, introduced efforts to widen contraceptive choice, to improve counseling, and to reach out to women's groups.
When the 1994 International Conference on Population and Development at Cairo ushered in a new wave of institutional opportunities to address gender issues, Caram took steps to broaden Profamilia's vision and mission. Caram also enjoyed strong support in this regard from IPPF/WHR's regional office. ${ }^{5}$ In 1995, Profamilia established a Women's Program and initiated a process of internal reflection on gender issues. Over a period of six months, the entire Profamilia staff (97 women and 47 men, including the Board of Directors) participated in workshops in which they explored such issues as the social construction of gender roles and inequity, women's sexuality and self-esteem, and the ways in which men control and influence women's reproductive decisions.

Caram conceptualized Profamilia's work on gender-based violence along two simultaneous paths. One was providing support services directly to women and girls who had experienced violence; the other was to initiate advocacy in the wider policy arena.

Profamilia hired psychologists and opened a free-standing counseling center, where women could talk about their problems, including their experiences with gender-based violence. As Caram recalled, "We thought that we would have waiting rooms full of women. But it wasn't like that. Women were very scared, and providers didn't refer them to us."

At the time, Profamilia fared better with the Congress.

\footnotetext{
${ }^{5}$ At the regional office, Judith Helzner was named Director of Program Coordination in 1987 and spearheaded efforts to promote attention to gender issues across all IPPF/WHR associations. Helzner fostered an organizational transition from services focused on family planning to a gender-based and sexual health approach. During her tenure, a number of trailblazing programs translated this approach into practice. See, for example, Ortiz-Ortega and Helzner (2003).
} 


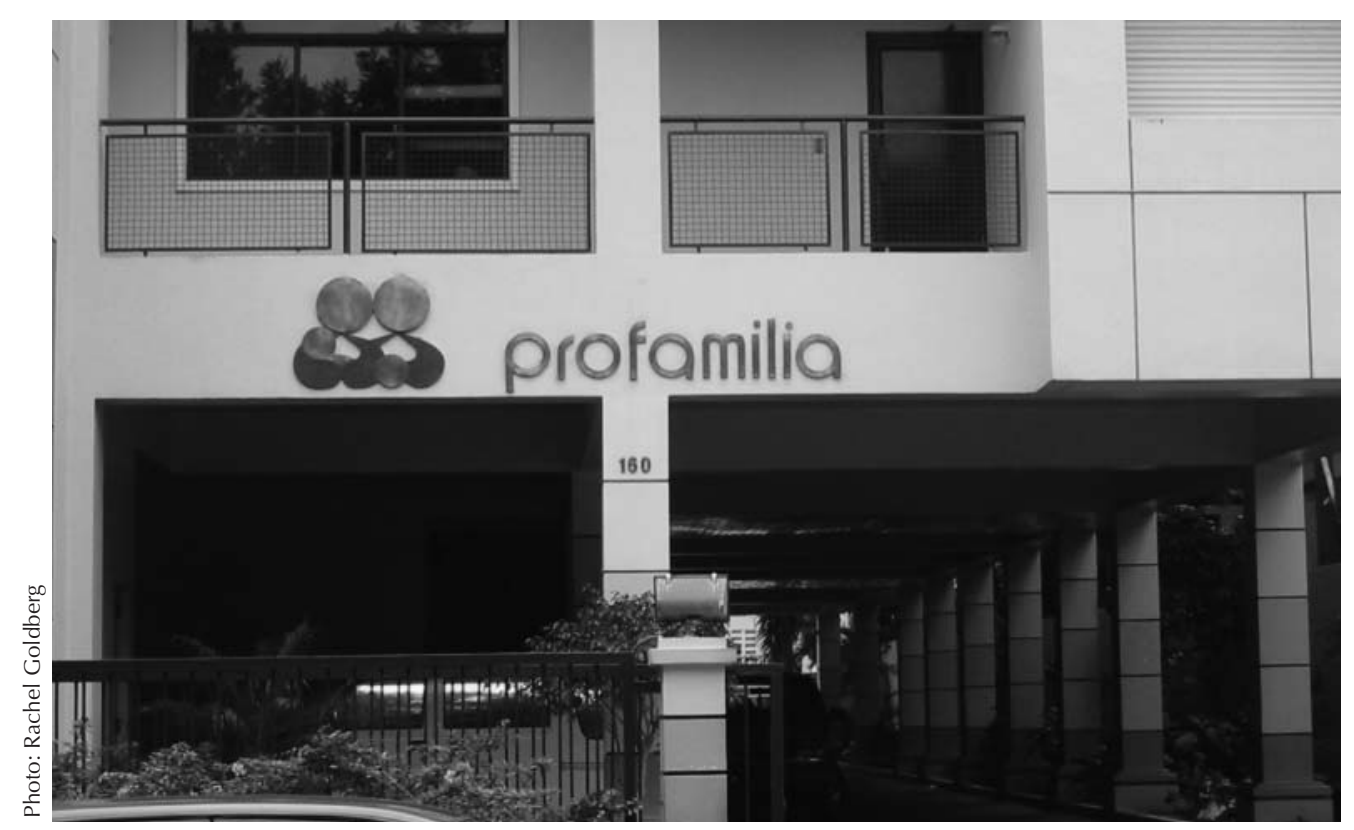

Profamilia, which annually provides nearly 200,000 sexual and reproductive health services (and more than 120,000 additional general health services) has a longstanding interest in gender issues. To lay a foundation for its work on gender-based violence, however, the organization rewrote its basic mission statement.

\section{Changing the Law Concerning Violence}

Awareness about gender-based violence in the Dominican Republic was growing, and the policy climate was shifting. In 1997, the president of the country convened a commission to develop and promote a law to increase protection against violence, especially domestic violence against women and children. Caram was one of a small number of NGO leaders who joined politicians on this commission. As early as 1996, Profamilia sponsored a high-level meeting at which legislators and NGO leaders agreed on the content of the proposed law and identified concrete steps for advocacy.

As the draft legislation passed through various committees, the commission members lobbied on its behalf. In their favor was the fact that politicians were courting women's votes for the upcoming national elections. Early in 1997, the Congress approved Law 24-97. The law explicitly criminalized violence against women, domestic violence, sexual assault, incest, sexual harassment, and harassment by telephone. The law allowed a victim of violence to obtain a restraining order against the perpetrator. Moreover, it mandated the creation of various services for victims of violence and their families, as well as therapy for aggressors. Finally, the law specified prison and financial penalties for each type of violence. A separate law dealt specifically with the abuse of minors.

As Caram remembers, "They didn't realize the significance of what they had passed."

Because the new legislation would mean little if women did not know their rights, the next step was to disseminate its contents. To explain Law 24-97 and the process for reporting violence, Profamilia compiled and disseminated three different publications, each aimed at populations with varying degrees of literacy. 


\section{Cooperation with IPPF/W H R ${ }^{6}$}

Caram was one of several executive directors in the IPPF system who convened with staff at the Western Hemisphere Region office to design a regional initiative to address gender-based violence at both the service and advocacy levels. ${ }^{7}$ They developed a proposal with the following objectives: (1) to improve the capacity of sexual and reproductive health services to care for women who experience violence; (2) to raise community awareness of gender-based violence as a public health problem and a violation of human rights; (3) to advocate for better laws and application of the laws related to gender-based violence; and (4) to increase knowledge about effective health-service interventions in the area of gender-based violence.

The regional planning team incorporated several basic principles learned in earlier attempts to integrate sexuality and HIV services into reproductive health care. ${ }^{8}$ First, rather than expecting a woman or girl to seek out a psychologist to declare herself a victim of violence, the clinic must actively screen clients. Second, screening must be routine, so that providers do not rely on stereotypes about a client's vulnerability. Moreover, screening should rely on specific questions that have been shown to enhance providers' and clients' comfort with the topic of gender-based violence. Use of such standardized questions also generates comparable data for evaluation across countries. Finally, to integrate attention to violence throughout the service, clinic staff at all levels require training.
With support from the European Commission and the Bill and Melinda Gates Foundation, the Western Hemisphere Region office provided start-up technical support to all three participating member associations. WHR hired a regional project coordinator (Alessandra Guedes) and an evaluation officer (Sarah Bott) to work with the three affiliates. At Profamilia, Magaly Caram hired Myrna Flores to coordinate all elements of the project and ensure their integration into the agency's work. Flores is an educator and counselor who came to Profamilia from a feminist organization. She recalls that when she joined Profamilia she knew that this work was "just what she wanted to do."

The IPPF regional office worked closely with the three member associations in developing detailed country workplans. Several planning workshops allowed staff to develop their definition of genderbased violence and to draft screening questions to ask clients. Although gender-based violence is sometimes narrowly equated with wife-beating or with violence at the hands of an intimate partner, the workshop participants included in their definition physical and emotional abuse by a partner or family member, sexual violence by any perpetrator, and a experience of childhood sexual abuse.

Participants also sketched out preliminary service protocols. Key elements included: providing written and verbal information about violence in the waiting room, ensuring privacy and confidentiality, asking the screening questions, assessing each woman's level of danger and establishing safety plans as needed, mak-

\footnotetext{
${ }^{6}$ The processes described in this section are also described in detail in several sources listed in the References section, including: Bott et al. (2004); Bott et al. (forthcoming); and Guedes et al. (2002).

7 The other Member Associations were INPPARES (the affiliate in Peru) and PLAFAM (in Venezuela). BEMFAM (in Brazil), which originally took part in the discussions, was not part of the formal project but continued to be involved in some of the regional activities related to gender-based violence.

${ }^{8}$ For an in-depth discussion of lessons learned by IPPF/WHR in a number of regional initiatives aimed at changing family planning services into sexual/reproductive health programs, see Helzner (2002). IPPF also drew on earlier experiences and dialogue within the field; see, for example, Moore and Helzner (1996).
} 
ing and documenting referrals, assuring that clients also received whatever services they were seeking in their visit, following up on referrals, and providing emotional and functional support to both clients and personnel. Profamilia decided to integrate the screening procedure into the standard medical history. As such, the doctors and psychologists (who take medical histories at Profamilia) were designated to conduct the screening and to refer clients to other providers as appropriate.

The regional planners, including evaluation staff from both the WHR and the member associations, emphasized the importance of developing systems for documenting the results and lessons of this groundbreaking initiative. Moreover, participants were aware that a poorly implemented routine screening intervention could put women at additional risk of violence or inflict emotional harm (Bott et al. 2004). They developed evaluation plans and standardized mechanisms for gathering and reporting service statistics. As Judith Helzner, who was the Director of Sexual and Reproductive Health for IPPF/WHR at the time, explained, "This project had the greatest integration of action and evaluation of any project in IPPF/WHR history." The close cooperation between programs and evaluation efforts allowed the staff to assess their actions and to make programmatic improvements continuously throughout the life of the initiative.

Finally, participants developed a joint regional strategy for advocacy activities, including organizing workshops, producing educational materials (for example, legal guides for medical providers), establishing political alliances, and disseminating information about the law.

\section{Building Institutional Will and Capacity}

As part of the initiative, Profamilia's Board of Directors revised the institution's mission statement. One of its five core objectives was "to promote gender equality and equity, improvement in the social condition of women, and the elimination of all forms of violence and discrimination against women." This statement created a formal context for the expanded, institution-wide work on gender-based violence.

Although a gender perspective had begun to penetrate the institutional culture, many providers felt that asking clients about their experience of violence would violate their privacy or was simply not relevant to the providers' own jobs. Providers also worried about whether they would be able to handle the difficult discussions and situations this work would engender. They felt, too, that the screening would take precious time from their already burdensome schedules.

Frank Alvarez, a longtime staff physician and the founding director of Profamilia's first clinic, recalls his own skepticism: "I didn't worry about [violence]. If the woman came with some kind of bruise, I thought perhaps she had fallen or that I didn't have to ask her about it. That it wasn't my problem.." ${ }^{9}$

The regional office planned a series of staff training sessions. The original plan was to use a training-of-trainers approach, but participants in the regional initiative realized that an understanding of genderbased violence was too complex for newly trained personnel to internalize and pass on adequately to others. Therefore, the regional office hired a single consultant ${ }^{10}$ to conduct a series of workshops varying in length and content depending on the job

\footnotetext{
9 Dr. Alvarez' remark is drawn from "Basta! The Health Sector Addresses Gender-based Violence," a video produced by IPPF/WHR, described on page 29.

${ }^{10}$ The consultant was María Cecilia Claramunt, a Costa Rican psychologist with extensive regional experience working with women who have experienced gender-based violence.
} 


\section{Training the Staff}

The trainings in the Dominican Republic occurred at various levels. For example:

- The entire staff (from receptionists to managers) attended an introductory session that aimed to increase their general understanding of gender-based violence and to reduce their resistance to working with victims of such violence.

- All physicians attended additional one-day courses at their clinic sites. An important task in engaging the physicians was to challenge their view that domestic violence is a cultural issue outside the realm of medical care. To help frame violence as a public health concern, the consultant first introduced data on its prevalence and health consequences, and subsequently on diagnosis, referral, and client care. The physicians also learned about the social, cultural, and personal factors that foster a cycle of domestic violence and that make seeking help difficult for victims. Factors that put women at risk of being murdered were also discussed.

- Profamilia's eight psychologists and counselors participated in a four-day training, to which representatives from several public agencies were also invited. In addition to receiving the information provided to the physicians, these staff were trained in crisis intervention, assessment of danger and psychological status, and safety planning. The long-term sequelae of childhood sexual abuse, fundamentals of longer-term therapy for survivors, and management of support groups were also discussed.

- A follow-up training several months later addressed legal issues and strengthened physicians' ability to ask the screening questions, assess danger, and make referrals.

description of the participant group. The first workshop was a week-long training for key staff from all participating countries; this course focused on the causes and consequences of violence, on helping women who disclose their experience of violence, and on strategies to prevent gender-based violence in the community.

Subsequently, Profamilia held training sessions in the Dominican Republic, led by the same consultant (see box above). Parallel advocacy activities are discussed in greater detail below.

Many providers reported that the training sessions transformed their attitudes toward their clients and their own work. ${ }^{11}$ As Dr. Alvarez remarked, "When one begins to learn about the issue, begins to talk about it, one realizes, 'Oh, that's what was happening with that woman.' You had [evidence that] you never thought about in that way before." Dr. Ricardo Mauricio added, "The workshops made one understand what the sit- uation really was: By dealing with the problem of violence one could prevent a death, just as one prevents a death by treating high blood pressure. When a woman who is experiencing violence comes in and we send her home, it is just like sending a man with high blood pressure and chest pains home."

Some providers worried about whether they could handle what might emerge from the screening. What would they do if the woman became emotional in the examining room? As the former coordinator of the youth clinic explained, "The greater concern of [some] providers was, 'What am I going to do if the client says yes?' The providers really wanted to be able to help their clients, and they were afraid they wouldn't be able to help sufficiently." Dr. Mauricio concurred: "We were very worried about how we were going to get involved in this problem, what we were going to do. But we learned how during the training."

\footnotetext{
${ }^{11} \mathrm{~A}$ baseline evaluation found that, in the past year, two-thirds of the providers had asked at least one client about violence, but in most cases they did so only when they saw signs or symptoms that led them to suspect a problem (Guezmes and Vargas 2003).
} 
At the same time, Myrna Flores also worked intensely to ensure providers' comfort as the issue of gender-based violence was integrated into their work. As she explained, because the goal was to institutionalize attention to violence, "the only way for the project to be successful was to take the providers into account at every step." Profamilia's team-based management structure greatly facilitated the project's ability to engage staff. Each clinic has what is called a "self-managed team" of five or six staff members representing different job functions. Flores met regularly with each of these teams, to discuss general concerns about the integration of the violence work and to propose changes in clinic protocols. The team members then discussed these issues with the staff they represented and relayed concerns and suggestions to Flores. Regional project coordinator, Alessandra Guedes, observed, "Because of this horizontal management structure, it took longer for the screening to be implemented in the Dominican Republic than in the other countries, but everyone implemented it."

In addition to working with the management teams, Flores and other managers engaged the rest of the providers directly during brown-bag lunches and round-table discussions. Gradually, the providers became more comfortable with the idea of integrating attention to genderbased violence into their everyday work. The enthusiasm of experienced physicians in management positions, such as Dr. Alvarez, helped garner support.

Anticipating a demand for in-depth counseling, Profamilia added two full-time and two part-time psychologists, one to supervise the others and organize regular casestudy reviews, in addition to seeing clients. Profamilia also anticipated a demand for legal services. Initially it entered into referral agreements with other institutions and eventually hired its own legal staff.

\section{Other Start-up Investments in the Project}

Before the screening could begin, Profamilia made a number of further institutional investments. One task was to develop a new information system so that staff could record cases of violence, and to designate individuals to enter these data into the system daily.

Profamilia also made capital improvements. It remodeled its clinics to ensure clients greater privacy in counseling. At the counseling center, additional soundproofed offices were added for the newly hired psychologists. In all of the clinics, staff revised client-flow plans so that women in crisis (upon arrival or after screening) could be routed immediately to a psychologist. Operating hours at the counseling center were also extended, so that a psychologist was always on the premises during the day.

Finally, project staff created a referral system. They began by identifying other local organizations working with victims of violence. After Flores visited each of these organizations, she created a referral directory, based on a template created by PLAFAM, the IPPF/WHR affiliate in Venezuela. Each listing in the directory includes information about the services offered, the population served, the hours of operation, and means of contact. The creation of the directory alleviated providers' concerns about opening a discussion about violence with a client because they knew they would have something to offer her. Moreover, building the referral network strengthened Profamilia's relationships with other organizations. Flores also created a two-part referral form: Profamilia staff fill in the first part with information about the client's needs; the client then takes the form to the next provider, who describes the visit and follow-up plan and returns the form to Profamilia. ${ }^{12}$

\footnotetext{
${ }^{12}$ As in many other projects, following up with clients in this manner has proved to be challenging.
} 


\section{The Screening Process}

When a client arrives at the clinic, she checks in with a receptionist, who helps to determine if her visit will include a consultation with a physician. Profamilia's protocol calls for one-time screening of all female clients aged 13 or older who see a physician or psychologist. Therefore, all new clients who are directed to see one of these providers automatically receive a blank screening form in their chart.

For returning clients, the receptionist pulls the chart and looks for a red V, the signal that the client has been asked previously about violence. If the $\mathrm{V}$ is not in the chart-for example, the client may not have visited the clinic for a few years - the receptionist puts a screening form in the chart. (Staff are aware that some clients who do not feel ready to discuss their experience of violence during an initial screening may wish to speak of the issue at a subsequent visit. The $V$ system is a management-information mechanism that triggers rescreening after a certain amount of time has elapsed.)

Typically, clients wait for more than an hour before seeing a physician. Information about gender-based violence is usually included in the waiting-room talks given by staff, as well as in leaflets and posters. For example, one poster reads "Domestic violence is more frequent than one might expect. Be careful; if anyone harms you and you need help, we are here to support you." A second poster, shown to the right, features Dr. Alvarez himself. These messages ease the subsequent screening process and inform all clients about the clinic's violence-related services.

At some point during the clinical history, the physician informs the client that Profamilia believes that a woman's bodily integrity and her freedom from violence are important dimensions of her health and that the clinic, therefore, routinely asks clients about their experience of violence; then the client is asked whether she consents to be questioned about this topic. Unless she refuses, the screening begins, first with a question about emotional violence, which is often the easiest sort of violence for women to disclose. The fourth question concerns childhood sexual abuse, which is often the client's most sensitive and guarded secret (see the box on the next page for the specific questions used on the screening form). The purpose of the final questions is to assess whether the client is in immediate danger.

The physicians were surprised by their screening experiences. Initially, they had worried that clients would not want to discuss such personal experiences and that they might even be offended by the questions. They learned that patients were willing, even eager, to speak about coping with violence. Dr. Evangelina Molina, the gynecologist at the youth clinic, added, "Clients have been much more willing to

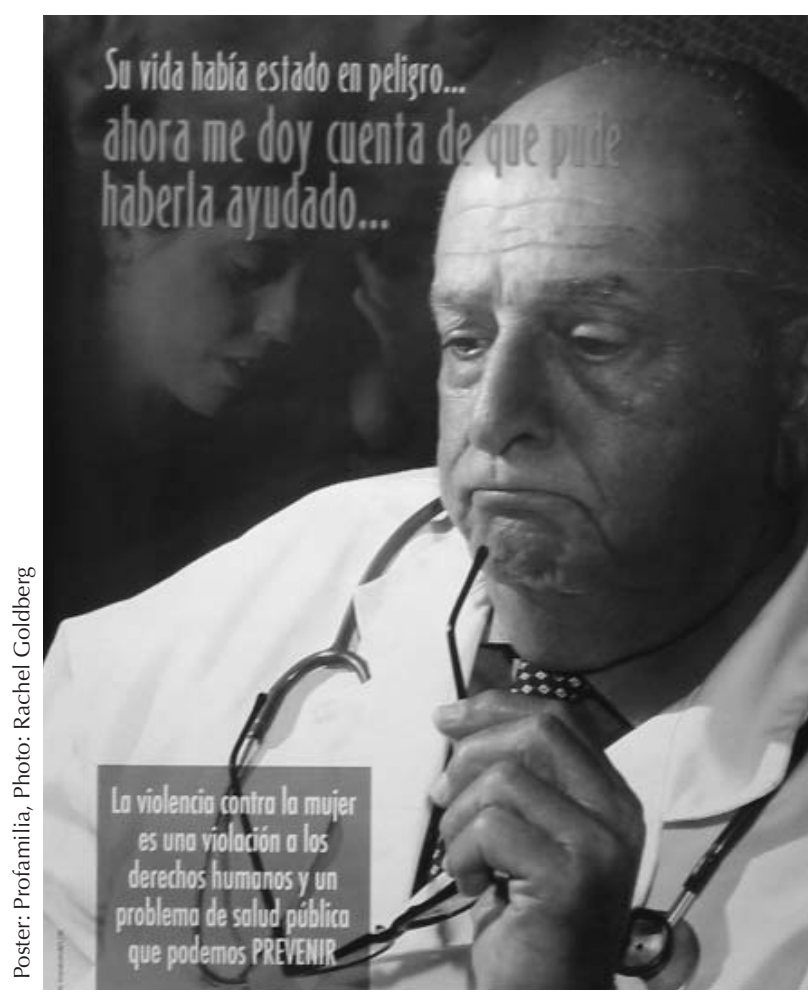

A waiting room poster quotes Dr. Alvarez: "'Her life was in danger. ... . Now I realize that I could have helped her ...' Violence against women is a human rights violation and a public health problem that we can prevent." 


\section{The Screening Form}

1.1 Have you ever felt harmed emotionally or psychologically by someone important to you? (Examples: constant insults, humiliation, destruction of objects you cared about, ridicule, rejection, isolation)

\begin{tabular}{|c|c|c|c|c|c|c|c|c|c|c|c|c|c|c|c|}
\hline \multicolumn{3}{|c|}{ Yes $=1$} & \multicolumn{3}{|c|}{ No $=2$} & \multicolumn{4}{|c|}{ Doesn't know $=3$} & & \multicolumn{5}{|c|}{ Doesn't answer $=4$} \\
\hline \multicolumn{16}{|c|}{ 1.2 If YES: By whom were you harmed? } \\
\hline \multicolumn{2}{|c|}{ Partner } & \multicolumn{2}{|c|}{$\begin{array}{l}\text { Ex- } \\
\text { partner }\end{array}$} & \multicolumn{2}{|c|}{ Parent } & \multicolumn{2}{|c|}{ Stepparent } & \multicolumn{2}{|c|}{$\begin{array}{l}\text { Uncle/aunt/ } \\
\text { sibling }\end{array}$} & \multicolumn{2}{|c|}{$\begin{array}{l}\text { Other } \\
\text { relative }\end{array}$} & \multicolumn{2}{|c|}{$\begin{array}{l}\text { Other known } \\
\text { person }\end{array}$} & \multicolumn{2}{|c|}{ Stranger } \\
\hline M & F & M & $\mathrm{F}$ & M & F & M & F & M & $\mathrm{F}$ & M & $\mathrm{F}$ & M & $\mathrm{F}$ & M & $\mathrm{F}$ \\
\hline
\end{tabular}

1.3 If YES: When did this happen?

\begin{tabular}{|l|l|l|l}
\hline Weeks ago & Months ago & Years ago & Doesn't know/Didn't answer \\
\hline
\end{tabular}

2.1 Has anyone ever harmed you physically? (examples: hitting, slapping, burning, kicking, biting, pushing)

\begin{tabular}{|l|l|l|l}
\hline Yes $=1$ & No $=2$ & Doesn't know $=3$ & Doesn't answer $=4$ \\
\hline
\end{tabular}

2.2 If YES: By whom were you harmed?

\begin{tabular}{|c|c|c|c|c|c|c|c|c|c|c|c|c|c|c|c|}
\hline \multicolumn{2}{|c|}{ Partner } & \multicolumn{2}{|c|}{$\begin{array}{l}\text { Ex- } \\
\text { partner }\end{array}$} & \multicolumn{2}{|c|}{ Parent } & \multicolumn{2}{|c|}{ Stepparent } & \multicolumn{2}{|c|}{$\begin{array}{l}\text { Uncle/aunt/ } \\
\text { sibling }\end{array}$} & \multicolumn{2}{|c|}{$\begin{array}{l}\text { Other } \\
\text { relative }\end{array}$} & \multicolumn{2}{|c|}{$\begin{array}{l}\text { Other known } \\
\text { person }\end{array}$} & \multicolumn{2}{|c|}{ Stranger } \\
\hline M & F & M & F & M & $\mathrm{F}$ & M & $\mathrm{F}$ & M & $\mathrm{F}$ & M & F & M & $\mathrm{F}$ & M & $\mathrm{F}$ \\
\hline
\end{tabular}

2.3 If YES: When did this happen?

\begin{tabular}{|l|l|l|l}
\hline Weeks ago & Months ago & Years ago & Doesn't know/Didn't answer \\
\hline
\end{tabular}

\begin{tabular}{|c|c|c|c|c|c|c|c|c|c|c|c|c|c|c|c|}
\hline \multicolumn{16}{|c|}{$\begin{array}{l}3.1 \text { Have you ever b } \\
\text { contact or intercourse }\end{array}$} \\
\hline \multicolumn{2}{|c|}{ Yes $=1$} & 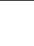 & \multicolumn{3}{|c|}{ No $=2$} & \multicolumn{4}{|c|}{ Doesn't know $=3$} & & \multicolumn{5}{|c|}{ Doesn't answer $=4$} \\
\hline \multicolumn{16}{|c|}{3.2 If YES: By whom? } \\
\hline \multicolumn{2}{|c|}{ Partner } & \multicolumn{2}{|c|}{$\begin{array}{l}\text { Ex- } \\
\text { partner }\end{array}$} & \multicolumn{2}{|c|}{ Parent } & \multicolumn{2}{|c|}{ Stepparent } & \multicolumn{2}{|c|}{$\begin{array}{l}\text { Uncle/aunt/ } \\
\text { sibling }\end{array}$} & \multicolumn{2}{|c|}{$\begin{array}{l}\text { Other } \\
\text { relative }\end{array}$} & \multicolumn{2}{|c|}{$\begin{array}{l}\text { Other known } \\
\text { person }\end{array}$} & \multicolumn{2}{|c|}{ Stranger } \\
\hline M & $\mathrm{F}$ & M & $\mathrm{F}$ & M & $\mathrm{F}$ & M & $\mathrm{F}$ & M & $\mathrm{F}$ & M & $\mathrm{F}$ & M & $\mathrm{F}$ & M & $\mathrm{F}$ \\
\hline \multicolumn{16}{|c|}{ 3.3 If YES: When did this happen? } \\
\hline \multicolumn{4}{|c|}{ Weeks ago } & \multicolumn{3}{|c|}{ Months ago } & \multicolumn{3}{|c|}{ Years ago } & \multicolumn{6}{|c|}{ Doesn't know/Didn't answer } \\
\hline
\end{tabular}

4.1 When you were a child, were you ever touched in an inappropriate way by anyone?

\begin{tabular}{|c|c|c|c|c|c|c|c|c|c|c|c|c|c|c|c|}
\hline \multicolumn{3}{|c|}{ Yes $=1$} & \multicolumn{3}{|c|}{$\mathrm{No}=2$} & \multicolumn{4}{|c|}{ Doesn't know $=3$} & & \multicolumn{5}{|c|}{ Doesn't answer $=4$} \\
\hline \multicolumn{16}{|c|}{3.2 If YES: By whom? } \\
\hline \multicolumn{2}{|c|}{ Partner } & \multicolumn{2}{|c|}{$\begin{array}{l}\text { Ex- } \\
\text { partner }\end{array}$} & \multicolumn{2}{|c|}{ Parent } & \multicolumn{2}{|c|}{ Stepparent } & \multicolumn{2}{|c|}{$\begin{array}{l}\text { Uncle/aunt/ } \\
\text { sibling }\end{array}$} & \multicolumn{2}{|c|}{$\begin{array}{l}\text { Other } \\
\text { relative }\end{array}$} & \multicolumn{2}{|c|}{$\begin{array}{l}\text { Other known } \\
\text { person }\end{array}$} & \multicolumn{2}{|c|}{ Stranger } \\
\hline$M$ & $\mathrm{~F}$ & M & $\mathrm{F}$ & M & F & M & $\mathrm{F}$ & $\mathrm{M}$ & $\mathrm{F}$ & M & $\mathrm{F}$ & M & $\mathrm{F}$ & $M$ & $\mathrm{~F}$ \\
\hline
\end{tabular}

3.3 If YES: When did this happen?

\begin{tabular}{|l|l|l|l|}
\hline Weeks ago & Months ago & Years ago & Doesn't know/Didn't answer \\
\hline
\end{tabular}

\begin{tabular}{|l|l|l|}
\hline $\begin{array}{l}5.1 \\
\text { Are you afraid of your partner or } \\
\text { anyone else close to you? }\end{array}$ \\
\hline Yes & No & Doesn't know \\
\hline
\end{tabular}

\begin{tabular}{|l|l|l|}
\hline \begin{tabular}{l} 
6.1 $\begin{array}{l}\text { Will you be safe when you return } \\
\text { home? }\end{array}$ \\
\hline Yes
\end{tabular} No & Doesn't know \\
\hline
\end{tabular}

\begin{tabular}{|l|l|l|}
\hline 7.1 Chart notes: Did you offer the client help? \\
\hline $\begin{array}{l}\text { Yes, and she accepted a referral to our } \\
\text { psychology services. }\end{array}$ & $\begin{array}{l}\text { Yes, and she accepted a referral to } \\
\text { other Profamilia services. }\end{array}$ & \\
\hline $\begin{array}{l}\text { Yes, and she accepted a referral to our } \\
\text { legal services. }\end{array}$ & $\begin{array}{l}\text { Yes, and she accepted a referral to } \\
\text { services outside of Profamilia. }\end{array}$ & \\
\hline $\begin{array}{l}\text { Yes, and she accepted a referral to our } \\
\text { medical services. }\end{array}$ & Yes, but she did not accept a referral. & \\
\cline { 2 - 3 } & No, did not offer her help. & \\
\hline
\end{tabular}

If you could not administer this questionnaire, please indicate the reason: 
talk than I expected, . . . but without our asking, they would not have communicated these things." Indeed, the physicians have modified the form to allow for more detailed and precise documentation; they also added room to note if, and under what circumstances, a client chooses not to respond.

Some back-and-forth may be required to ensure that client understands the screening questions. Dr. Román explains: "Sometimes clients are not sure what we are asking, especially with the first question. So I clarify what I mean with simple examples so that she can recognize and respond a question about whether she has experienced that type of violence."

\section{When Women Disclose Violence}

About one in seven women responds positively to at least one of the screening questions (Bott et al. 2004). ${ }^{13}$ For example, 52-year-old Silvia immediately replied: "Yes! Yes. But it was a long time ago. . . . My previous husband hit me a lot. I suffered greatly; that's why we split up. . . . He tried to force me to have sex, but I didn't let him. So we had lots of problems."

Silvia was able to respond comfortably, even about sexual abuse during her childhood. "Yes. I was raped when I was 15 or $16 . .$. The first three months were very difficult. I couldn't eat, or sleep. . . . I wanted to die, but I had a boyfriend who really supported me."

When a client discloses any experience of violence, the provider offers support, informs her that Profamilia offers services to women in her situation, and asks if she would like to follow up. The provider does not, however, pressure a client to take action if she does not feel comfortable about doing so.

\section{Follow-up}

On average, fewer than half of the women with a history of abuse (43 percent) accept a referral for further attention (Bott et al. 2004). Among the cases observed by the author were the following:

Margarita, age 35, explained that her ex-husband had abused her sexually, physically, and emotionally. After they separated, he continued to "bother her a lot." She was currently in a different relationship, with a man who treated her well. Margarita declined to speak with the psychologist, but mentioned that doing so might have been useful earlier, when she was still "dealing with it a lot." The doctor reiterated that the staff were happy to help at any point in the future and continued to the next section of the clinical history.

Sofia, in her fifties, reported that her husband had been psychologically abusive "a year or so ago," but this did not involve physical or sexual violence. She explained that she did not need a follow-up referral.

Typically, if the woman indicates an interest in obtaining a referral, the physician completes the examination, thereby ensuring that the client receives the service for which she originally came to the clinic. The client may then arrange a follow-up appointment for another day.

If, however, the client explains that she is currently in danger, or if she becomes highly emotional as a result of disclosing her disturbing experiences, the physician dispenses with the rest of the exam and sends her to meet immediately with a psychologist (or, if the psychologist is not available, with a coun-

\footnotetext{
${ }^{13}$ Typically, disclosure occurs within the context of screening administered by a physician. Some women do not see a physician, but spontaneously disclose violence to other providers. As one counselor explained, "A woman may drop in for family planning or HIV testing, and then the [subject of violence] emerges."
} 
selor). ${ }^{14}$ The clients who most frequently become distraught during counseling are those who are disclosing childhood sexual abuse; often they are speaking of it for the first time in their lives.

Clients who visit the clinic for HIV testing (who typically see a counselor rather than a physician) may also be in crisis. As one counselor explained, helping clients navigate between HIV infection and violence is particularly difficult. "For example," she said, "a woman who is diagnosed as HIV-positive . . . often tells me, 'If I tell my partner that I'm positive, he's going to kill me.' "

The key task in crisis-intervention counseling is to evaluate the necessity of taking immediate measures to protect a woman's well-being. Ana Gloria Garcia, a clinic counselor commented on the challenge involved in trying to honor a woman's autonomy while attending to her safety:

\section{Sometimes a client doesn't consider} herself to be in danger. If I deem her to be at high risk, I don't make an appointment for her with the psychologist for another day. She must be seen immediately. . . . At times we've had to put a woman in a taxi to send her to the authorities, with a direct contact name, to report her situation and take out a restraining order. She does not leave here until we are sure that she is not going to be in danger.

In theory, the psychologist can refer a woman facing immediate danger to a women's shelter. The reality, however, is that until 2004, no women's shelters existed in the country, and currently only a handful are operational. In any case, many women do not want or need to leave their relationship immediately,

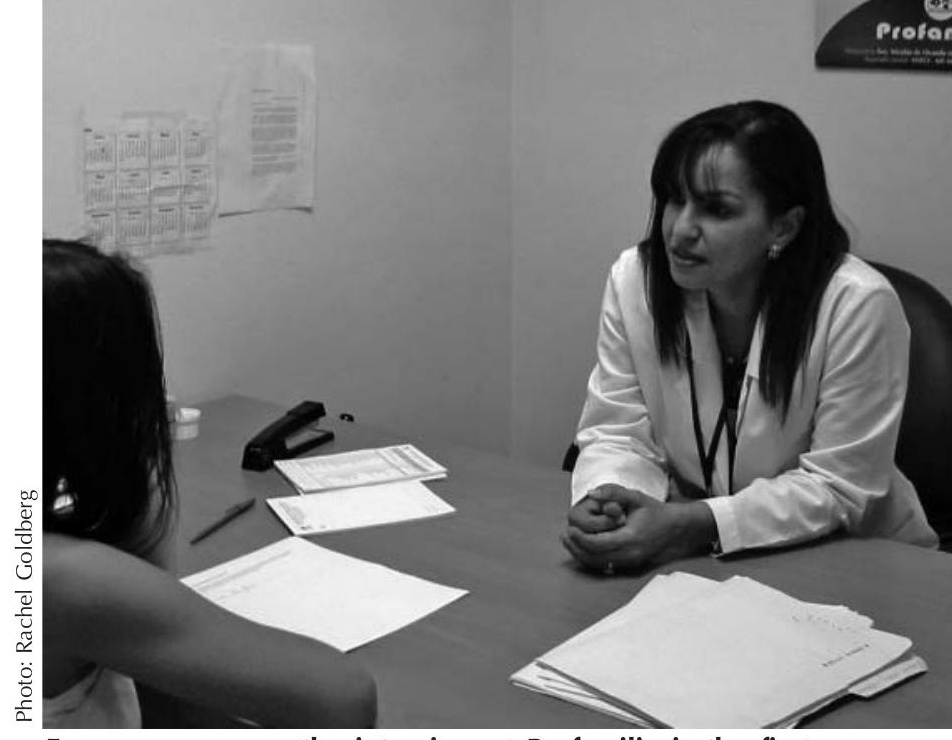

For many women, the interview at Profamilia is the first time anyone has listened to them talk about their experience of violence.

and the staff typically help the client identify a few strategies for protecting herself and her children in case of emergency.

Mildre Nolasco, the supervising psychologist at Profamilia, described how the organization helps clients in danger to pursue alternative strategies: "When there is a history of physical violence and a profile suggesting that it may continue to recur, we work on safety plans. We identify steps she can take, within various limitations, to avoid violence." These options may include: during unavoidable conflicts, staying away from rooms where exit is difficult or where weapons are kept; planning escape routes and places to go to in case of an emergency; asking one or more trusted neighbors to call the police or other community members if they see or hear what appears to be an episode of violence; preparing children to go for help in the case of a violent incident; packing a bag with important documents, money, and clothes in case she has to leave home in a hurry, and storing it discreetly in an accessible place (Bott et al. 2004).

\footnotetext{
${ }^{14}$ Profamilia doctors are not certified by the state to conduct forensic examinations; thus, their exam results cannot be considered to be forensic evidence. The client who is visibly bruised or otherwise injured from a beating must be referred to the office of the public prosecutor to report her case and to be examined immediately by a forensic doctor; if necessary, a Profamilia staff member will accompany her to the prosecutors' office. Similarly, if the physician suspects abuse of a minor, the staff lawyer assumes the responsibility for reporting the case (as required by law) and for sending the minor to a forensic physician.
} 


\section{Follow-up Counseling}

Although most of Profamilia's violence-related counseling caseload is generated from its clinic population, some clients are referred from other agencies. For example, the office of the public prosecutor regularly sends women to Profamilia for a psychological assessment, which becomes part of the woman's official file.

Clients may meet with a psychologist on a short- or a long-term basis. They pay for sessions on a sliding scale, up to 400 pesos (US\$12) for the first session, and 300 pesos (\$9) for subsequent visits. The service is free, however, to those who cannot pay.

The psychologist's objectives are to help a woman coping with the risk of violence to articulate her feelings, to clarify her goals, and to develop a plan to achieve those goals and the skills and emotional strength to implement her plan. Many women face significant challenges in carrying out their plans. For example, some accede to unwanted sex as a way to protect themselves from physical violence or cope with violence in order to maintain a relationship. Women's financial autonomy is an important issue. Obviously, the decision to remain in or leave an abusive relationship is a complicated one (see box on right).

Even for women who want to leave a relationship, the lack of shelters for women seriously constrains short-term alternatives. Moreover, women who experience violence, particularly those who have been living with abuse for years, are often socially isolated and lack close friends. Even family members may discourage a woman from leaving an abusive relationship, largely in the hope of keeping the family intact for the sake of the children.

Mildre Nolasco explains that she sometimes experiences "a certain feeling of impotence" in trying to help women who have little or no social support and no residential shelters open to them.

A crucial element of the counseling process, therefore, is helping clients to

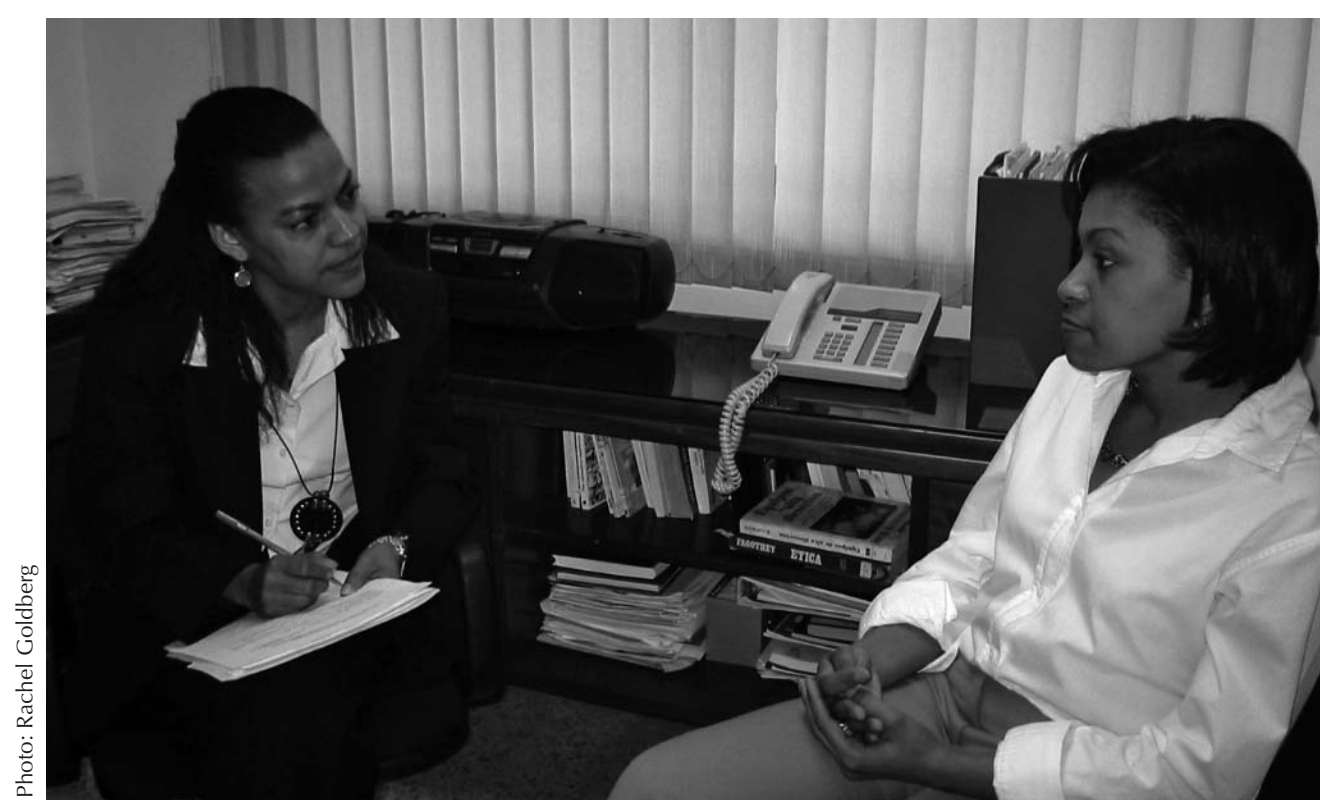

Women who live with abuse for years are often isolated and lack close friends. Staff may talk to a victim of violence about every person in their lives, hoping to identify someone who can offer a lifeline of support. If a woman is at risk of facing continuing violence and leaving her home is not a viable option, the counselor helps her develop an emergency safety plan. 
develop a support network. At Profamilia's youth clinic, psychologist Carmen Lirio talks with girls about every person in their lives, hoping to identify someone who can offer a lifeline of support. She says, "Even if the violence is within the family, there may still be an aunt or a cousin . . ." Nolasco adds, "We monitor (the girl's) plan over time and adjust it as needed, and particularly work on constructing a support network." If a client is extremely depressed or anxious, the psychologist may also recommend a psychiatric consultation to consider medication.

\section{To Stay or Not to Stay}

Initially, 23-year-old Milagros denied having had any experience of violence. When she returned for her next appointment at Profamilia, however, her situation had reached a crisis point, and she knew that she could ask the doctor for help. Milagros explained that as a child she had been beaten by her father and reported that her current partner-with whom she has four children-was abusing her physically, emotionally, and sexually.

Milagros was sent first to the clinic counselor and subsequently to the staff psychologist, who also referred her to a psychiatrist for medication. She has continued to seek care over the long term because she faces ongoing crises. At one point, her partner kidnapped two of her children; she did not see them for nine months. She is no longer living with her partner, although he has remained present in her life. Milagros states that "Profamilia staff have made a huge difference for me, and they have treated me for free because I cannot afford their services. If I had not done something, I would have died."

Rosa had been married for $\mathbf{1 4}$ years, living in a situation of acute physical and emotional abuse. When she made the difficult decision to leave her husband, a woman who worked at her church referred Rosa to Profamilia. Rosa recalls her state at the time: "I felt like I didn't exist. I didn't want to live or to do anything."

Rosa found her separation extremely painful. She explained, "After 14 years, love doesn't go away from one day to the next." Two months into the counseling process, she reconciled with her husband. She soon discovered that he was having another relationship, however, and she decided to pursue a divorce. With Profamilia's support, Rosa went to the office of the public prosecutor, and last year her divorce was finalized. She reports, “When I came to Profamilia, I didn't have the energy to face the situation. Thanks to the staff I was able to see that life goes on. With their support I have overcome many challenges."

Dolores ${ }^{15}$ explains that she had stayed in her relationship out of fear of physical harm and fear of losing her children, because, she says, "he always told me that if I left him, no matter where I went, he would find me and kill me. He told me that he always kept ... a machete . . sharpened, on hand, to chop off my head . . . and that if they threw him in jail, when he got out, he would find me and kill me. But then I met Tamara. I work in a beauty salon, and she came in and saw me crying. I used to cry a lot. She asked me why I was crying, and I said, 'I have a huge problem and I'm going crazy.' I told her about . . my husband's abuse. I said I didn't want to leave because I didn't want to abandon my kids. She gave me the number of the psychologist at Profamilia. She said, 'You can't go on like that. These people can help you.' And from there I began to heal. . . . Every time I saw I had taken a step, I was better able to overcome this fear. I felt, 'Oh, I can. And if I can, I'll keep moving forward.'"

\footnotetext{
${ }^{15}$ Dolores' remarks are drawn from her participation in Basta! Women Say No to Violence, a video produced by IPPF/WHR about their regional violence initiative (see description on page 29).
} 


\section{The Need for Legal Services}

Among Profamilia's clients, a small proportion-about 2 percent of those who acknowledge some past or current experience of violence-accept a referral to legal services. During the early phase of the project, staff referred women to one of two national institutions that offer legal services to survivors of violence, and, if necessary, gave them a coupon to receive those services without charge. In 2000, Profamilia began to form a small legal staff. They hired Janet Camilo to advise clients concerning legal matters and to counsel the project team about relevant legislation and advocacy efforts (see page 26 for a description of these advocacy efforts).

For those who consider legal action, the psychologist arranges an appointment with a Profamilia lawyer and, if possible, accompanies the client to the session. Clients pay 50 pesos (\$2) for a legal consultation. (If no Profamilia lawyers are available, the psychologist refers the client to one of the four lawyers at the Ministry of Women, where services are free.) The lawyer tries to give the client a clear sense of her options. As Janet Camilo explains, "I present her with a platter of choices, telling her, 'You can do this, this, and the other.' I explain to her the consequences of each action so that she can make a choice herself."

The number of women who file charges against their aggressors is small, primarily for two reasons: First, as Mildre Nolasco explains, "What the majority want is not to separate from their partners, but to be free of violence. In other words, they fall into the trap of thinking that their partners are going to change." Second, even those who want to separate from their husbands or obtain a divorce, child custody, and/or alimony, generally prefer not to take legal action.

The path of a woman who decides to press charges against an aggressor is affected by the complexities of the legal system and by the woman's feelings. At a minimum, it requires the following actions:

The first step is to place a complaint. The government has designated 11 public prosecutors' offices where specially trained staff are available to receive complaints about gender-based violence. Because as many as 100 women file complaints each day, a complainant may have to wait in line for hours to see

\section{The Case of Crucita}

For large cases, Profamilia lawyer Janet Camilo sometimes collaborates with attorneys from sister agencies. One such case involved a 17-year-old girl who was kidnapped by her ex-boyfriend months after ending their relationship. He drenched her in acid, burning her whole body. The crime received much attention in the media and is known as the case of Crucita. When Crucita emerged from the hospital, Profamilia approached her to offer legal support. Camilo and her colleagues prosecuted the case, and the attacker was sentenced to a 30-year prison term (which he is appealing). Meanwhile, Myrna Flores found funds to enable Crucita to undergo reconstructive surgery in the United States. Profamilia provided all services to Crucita at no charge. 
the prosecutor. After a woman files her complaint, the public prosecutor may send her to a forensic physician to be examined.

Based on the written complaint and the medical report (if one is presented), a judicial official decides whether to order an arrest warrant. Sometimes the woman must deliver the warrant document herself to the perpetrator. According to Camilo, "This [procedure] is one of the problems we have in the system. Can you imagine what it's like [for these women] to have to hand the arrest warrant to their aggressors in order to send them to prison? Often [the women have] to give a little [money] to the police to [obtain their help in delivering the warrant]."

Assuming that the woman summons the courage to deliver the warrant, the alleged aggressor must report for questioning. He is held for 48 hours, during which time the prosecutor weighs the evidence and determines whether to release him or to forward the case for further investigation and possible trial. If the prosecutor releases the aggressor, the woman may still request a restraining order (requiring the man to stay away from her), but this process involves going to the police again and asking them to accompany her while she confronts her aggressor with the restraining order.

At first, the legal staff tried to accompany women through the entire legal process. (Profamilia does not charge the clients for legal services beyond the initial 50-peso fee.) The lawyers soon found that too many clients needed their services, however, and that a large proportion of the clients did not follow their cases all the way through the system. Camilo explained, "Being only one person, I could not represent all of the women who came to me." Although she still occasionally accompa- nies a woman to the public prosecutor's office, the legal aid program has shifted to become a carefully monitored system. Camilo calls public prosecutors whom she knows personally

The government has designated

11 public prosecutors' offices

where specially trained staff are

available to receive complaints

about gender-based violence.

Because as many as 100 women

file complaints each day, a

complainant may have to wait in

line for hours to see the prosecutor.

and tells them that she is sending a client to them. She gives the woman a Profamilia referral form to present to the prosecutor. She also reminds the woman that she can return if she needs a lawyer, and that someone at Profamilia or at the Ministry of Women will assist her.

Camilo has spent an increasing proportion of her time on public policy issues. She explains, "We realized that we needed to involve ourselves most deeply in strategic cases that could affect public opinion and create judicial precedent ... [and ] to represent those women whom we felt were at the highest risk." (see the box on p. 18: The Case of Crucita). She adds, however, that "No woman leaves here without a solution. If she makes a decision to do something about her situation, we find a way for her to feel that she is being supported and accompanied through the process. This is critical for the process to work." 


\section{Screening Results}

At the beginning of the initiative, between January and June of 2001, 24,144 Profamilia clients responded to the violence-screening questions. A large proportion of the client population has now gone through the one-time screening for gender-based violence, although staff still screen more than 16,000 women and girls every year.

Data for 2002 show that 14 percent $(2,280)$ of clients reported situations of past or current abuse, varying from 6 percent in an urban clinic serving mostly adult women to 30 percent of girls attending the youth clinic. Of these clients, more than one in four (27 percent) reported experience of sexual abuse during childhood, nearly one in three (30 percent) reported experience of sexual violence, nearly a half (46 percent) reported physical violence, and slightly more than three-fourths (76 percent) reported emotional or psychological violence. ${ }^{16}$ That these figures represent a slight increase over the rates found during the first six months of the project may suggest that, with time, the physicians developed greater comfort and skill in asking about these sensitive topics or that survivors became aware of the gender-based violence services provided and actively started to seek them.

\section{Clients' Response to Violence Screening}

About 14 percent of all screened clients disclose violence, a third of whom seek further counseling after their disclosure; a much smaller number (2 percent of those who report violence) seek legal services.
A midterm evaluation conducted across the three countries found that clients who had disclosed violence particularly valued the chance to speak with providers:

The good thing is that they don't judge you, and this enables you to talk.

We [adolescents] feel comfortable because we know that others will not find out.

This was the first time that I felt that I was taken seriously and that they [providers] believed my story.

When I told my story, the provider made me feel secure; she gave me courage, she gave me strength. ${ }^{17}$

Women's discomfort about disclosing their experience with violence was further documented in a cross-sectional study conducted independently by Dr. Luis Payán among 435 female clients at the Profamilia clinic and at a second clinic where he works. Dr. Payán found that fewer than half of the women who had reported emotional or physical violence had ever told anyone about their experience; the disclosure rate was less than 25 percent among those who had experienced sexual violence.

How do the majority of clients who do not report violence-because they have not experienced abuse, do not recall it, or are not comfortable discussing it-feel about the screening process? Data concerning this question are drawn from several sources. ${ }^{18}$

An exit survey conducted in the Dominican Republic showed that clients valued the screening process: 97 percent of clients who were screened (and 92 percent of those who were not) felt that

\footnotetext{
${ }^{16}$ A separate analysis carried out by a staff psychologist found that between 1999 and 2002, among female and male adolescents seeking psychological counseling at the youth clinic, 50 percent of girls and 20 percent of boys reported having been sexually abused.

${ }^{17}$ These quotations are drawn from the midterm evaluation (Guezmes 2002). The midterm findings are also discussed in detail in Guedes (2002); Bott et al. 2004 and Bott et al. (forthcoming).
} 
providers should ask about exposure to violence (Guezmes 2002). Ninety-one percent of those screened said they felt good about or comfortable talking with the provider about gender-based violence (Guezmes 2002).

In interviews with the author, one woman explained that the questions were unexpected, but that asking them was a good idea that could help "protect women and [their] children." Another commented, "I felt strange because doctors don't usually ask these things. Not uncomfortable, just surprised."

In Profamilia's view, even those clients who do not report experience of violence benefit in some way from the screening to the extent that the nonjudgmental exchange raises their awareness about this problem as a public health issue that doctors understand is sensitive and about which they care a great deal.

\section{How Physicians Changed}

The final evaluation of the project after three years found that providers had changed their attitudes and practices dramatically. ${ }^{19}$ For example, 100 percent of Profamilia providers agreed that healthcare providers should ask female clients systematically about violence. Dr. Payán, an experienced obstetrician-gynecologist, commented, "Of about a thousand women of whom I've asked these questions, only one, about three years ago, told me that she didn't want me to ask them."

At interviews for the final evaluation, Profamilia providers described how the project had changed them. Eighty-four percent reported great improvements in their knowledge, 92 percent reported changes in their way of thinking, and 89 percent reported that being involved in the project changed the way they work.

Physicians' Attitudes Related to Gender-based Violence, Dominican Republic

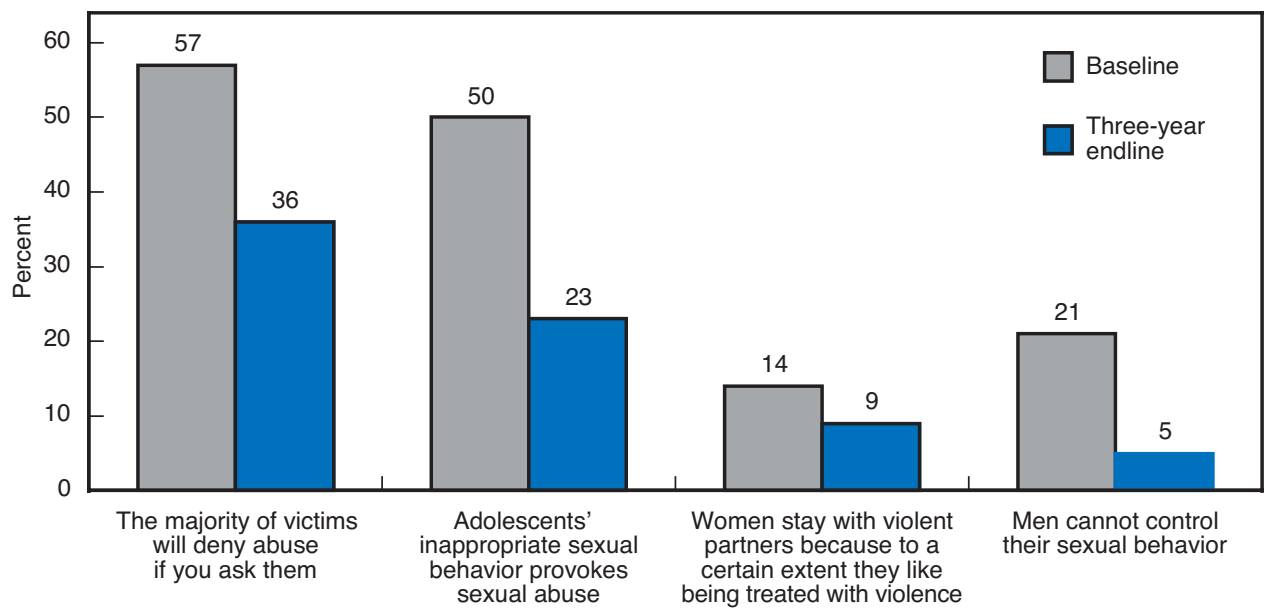

\footnotetext{
18 The project uses several methods to assess its effectiveness. Baseline and follow-up surveys have been implemented, consisting of KAP surveys with Profamilia providers and with facility surveys. In addition, at midterm a consultant conducted group discussions with providers and with women who had experienced violence. The consultant also carried out in-depth interviews with women who had experienced violence, and with key informants from the associations and from other Dominican organizations. Quantitative data about clients' perspectives were also gathered by means of an exit survey among 201 female clients attending Profamilia clinics. The baseline evaluation methods are described at length in Guedes et al. (2002) the methods for the midterm and final evaluations are described in Guedes et al. (2002) and Bott et al. (2004).

${ }^{19}$ The data given in this section are from the final evaluation report prepared by Guezmes and Vargas (2003). Although the report covers all three programs, only the Dominican Republic data are cited here. The evaluation results are given in more detail in Bott et al. (2004) and in Bott et al. (forthcoming).
} 
Fifty-nine percent of doctors felt adequately prepared to speak with clients about violence, compared with 14 percent at baseline. At three-year followup, 100 percent of physicians reported that at least one client had disclosed violence to them at some point.

As the chart on page 21 demonstrates, Profamilia providers' tendency to blame victims of gender-based violence fell dramatically. For example, the proportion of doctors who agreed with the statement "Adolescents' inappropriate sexual behavior provokes sexual abuse" fell from 50 to 23 percent. Those agreeing with the statement "Men cannot control their sexual behavior" dropped from 21 to 5 percent.

The doctors also learned to consider how living with violence can affect a woman's risk of disease and unwanted pregnancy. They became sensitized to the issue of violence in their own practice, beyond the screening process. Dr. Payán explained, "A woman may be afraid to use any [family planning] method that her husband might not want her to use." Dr. Mauricio added, "Sometimes asking her husband or partner to use a contraceptive can be an excuse for him to become violent." He spoke poignantly about the case of a woman he treated before Profamilia had initiated its gender-based violence services:

I advised one patient not to have sex for a week. She returned a week later, with a bruised face, and she told me that because of my advice she was beaten. She said, 'You told me not to have sexual relations, and I didn't want to have them, and Imy husband] beat me because of that.' I now realize that I always need to ask a patient whether she feels comfortable with the course of action I recommend. Will she be able to do it? Will she be safe?

\section{Providers' Satisfaction in Their Work}

Some physicians had worried that the screening would lengthen their consultations, resulting in less patient volume overall and an increased work burden in general. In practice, this was not the case. As Dr. Mauricio remarked, "We thought that the project might decrease production, and the doctors all earn money based on their production. . . . This was the main reason for their hesitation, and we found that in practice, [decreased production] was not an issue." Dr. Alvarez agreed, adding, "At the beginning, one of the criticisms that we made was that we were weighed down with work, and that the screening was going to mean more work. But in the end [the increase] has not been significant."

Dr. Alvarez adds that screening for violence has strengthened providers' diagnostic skills:

What you gain in terms of increased quality in the consultation compensates perfectly the minimal added time. It's time that you use for something that aids diagnosis. If you can't make the proper diagnosis, you can't cure the patient. It's part of the consultation, not an extra piece.

For example, she might have pain in her pelvis . . that I can't diagnosis or cure because I didn't understand the etiology of the condition. Some women come in every week, and all their exams are normal. You open the door and think, 'That woman again; I don't know what I can do for her.' Doctors spend months and months, years, dealing with a patient, and finally they might realize that part of what is going on is violence.

Dr. Mauricio concurs, saying, "Physicians who treat women are not fully trained until they have been taught how to deal with the consequences of vio- 


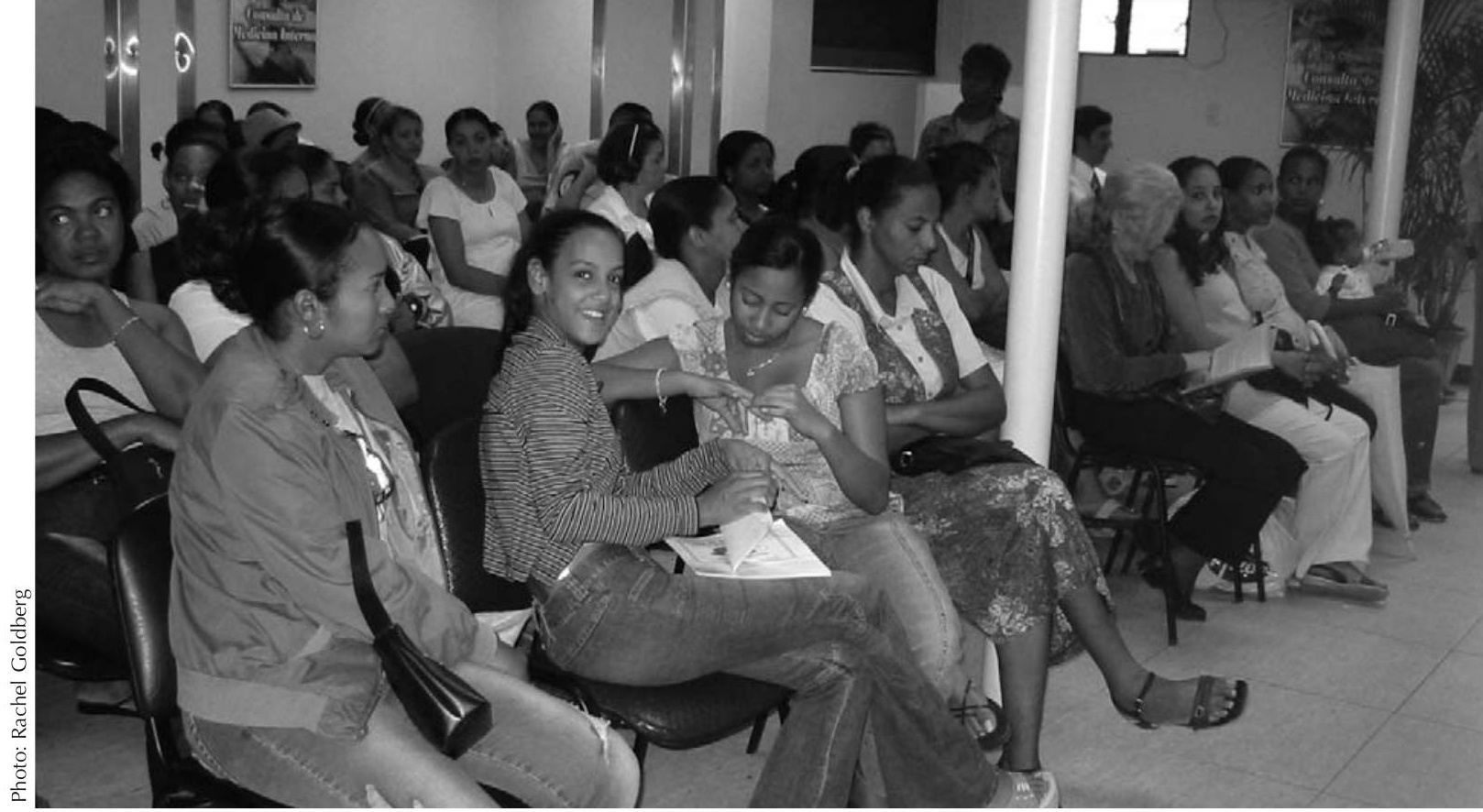

In response to the screening, one in seven clients chooses to disclose the violence in their lives to her provider at Profamilia.

lence. They are probably diagnosing many things incorrectly because of their lack of knowledge."

Providers also feel positive about the impact their work can have on a woman's life. They recognize that many women are entrusting them with information they have held as a secret burden for many years, having had no one they could trust. Dr. Alvarez observed:

I think that one of the most important things we can do is to help a woman to understand that she is suffering violence. Sometimes she thinks that this misery is a normal part of life, that all men behave like that. And suddenly, with help, she comes to realize that she is being abused.

The most gratifying aspect of this work has been finding that. . . women see me in a different light after I ask these questions. They recognize me as being interested in their problems. I think that providers have grown in these women's eyes because we have shown them that we are interested in more than their physical symptoms, that we care about their whole person.

Nolasco recalled a woman who had been referred from the Ministry of Women:

I asked her the screening questions, and she opened her eyes and said, 'But this is incredible. I didn't know that I was an abused woman.' The most gratifying aspect of this work is when one sees that a woman is making progress for herself and her children. She is taking steps on the path.

Some providers feel that this work has affected them personally as well as professionally. One gynecologist reflected:

I began to change. First by changing at home. I began not to speak so harshly to my daughters, not to fight so much with my wife. I thought how can I argue or be violent at home and then tell women 'I know how you feel. I'd feel the same in your place?' How could I give them support when I was living a double standard? So for me it has been wonderful. ${ }^{20}$

\footnotetext{
${ }^{20}$ This quotation is drawn from the video "Basta! The Health Sector Addresses Gender-Based Violence" (see page 29). It is also cited in Botts et al. (2004), page 79.
} 


\section{Ongoing Challenges}

Because few examples of other programs existed as models, and because this work was so new to Profamilia, challenges inevitably occurred along the way. Some were unexpected; others were not. Some were beyond the staff's control, and others were easily fixed.

\section{Meeting Clients Alone}

Providers still have difficulty meeting with some clients without their partners or family members present. (At the threeyear evaluation, 26 percent of providers cited lack of opportunity to speak with clients alone as a barrier to screening.) This difficulty serves as a reminder that efforts to increase male involvement in reproductive health care must protect a zone of privacy in which a client can state confidentially whether and at what point she would like someone else to be in the room with her. Providers are concerned that women whose partners refuse to leave may be particularly vulnerable to abuse.

Nolasco explained, "Sometimes I give the man some work to do, like writing something for me out in the waiting room. Or I spend time with him alone first, so as not to aggravate the situation .... At times the tension is so great that I cannot conduct the screening." Dr. Payán added, "If a woman's partner accompanies her, I ask him to leave the room so that I can ask her some questions that are to be answered by her alone, and that even the nurse will not be present. If he does not accept, I can do nothing. I note this situation on the screening form." At the youth clinic, parents, particularly mothers, may insist on accompanying their daughters during the entire visit. The doctor there said that this is a common reason that she is unable to conduct the violence screening.

\section{Privacy and Security}

Although the clinic rooms are soundproof, the three-year evaluation found that staff continue to enter consultation rooms while providers are with clients.

Over the course of the project, Profamilia has had to learn how to protect the safety of its staff and its clients. As clinic manager Salvador Piñeyro remarks, "We didn't know how to handle the security issues at first. . . . We started to see very sensitive cases ... men threatened the psychologist, or wanted to obtain their partners' charts." Early in the project, a man entered a clinic with a gun and threatened the psychologist.

All of the clinics now have trained their security staff, explaining the work that goes on inside and teaching them how to identify and respond to danger signs. As Camilo explained, "The guards operate from the premise that they do not know anyone here. If someone comes looking for a client or if they think that a visitor is potentially dangerous, they will not allow that person to enter the building. If they are in any doubt, they get in touch with a supervisor." At one of Profamilia's new clinic buildings, a second security station has been added at the internal entrance to the counseling, psychology, and legal section.

\section{Follow-up for Physicians}

The violence-screening protocols were purposefully designed in a streamlined way that does not require physicians to provide the follow-up counseling related to domestic violence. The physicians, however, are increasingly frustrated by this lack of continuity; they want a mechanism for learning what happens to a client after she leaves their office. As Flores said, "We wanted to make everything easy and fast for the doctors, but this is one of the things we need to resolve." 


\section{Support Groups for Survivors}

Because victims of violence are often suffering from social isolation, support groups are a potential source of validation and solidarity. As Nolasco explained, "Our experience confirms that support groups are a useful tool. At first, the women were afraid to speak about their situations with others, but after they had done so, they felt more powerful." Support groups may also be a more comfortable option for those women who do not want to see the psychologist because they feel, understandably, that the perpetrator is the one who is "crazy" and needs psychological help.

At the beginning of the project, Profamilia had difficulty organizing and maintaining support groups. As Nolasco remarked, "The women who come here have a lot of fears about talking about their problems outside of a private consultation. But we [also] weren't active enough in setting up the groups." Recently the therapists have facilitated several ongoing groups successfully, including some that are organized specifically for victims of incest.

\section{Dealing with Clients Who Choose To Do Nothing}

Women choose to remain in violent situations for many different reasons. Accepting this choice has not been easy for providers, who are trying to help women live free of violence. Dr. Mauricio commented, "The most difficult thing is realizing that the women are right: For financial reasons, they have no other option. . . In practice, I have not been able to find many words to say to these women, when they tell me so clearly what their situations are. I tell them that we are here if they would like help at some point."
The providers have come to realize that sometimes just knowing that emotional support and help are available can be important. Dr. Mauricio stated, "I have always felt that even if the woman doesn't want any help, the fact that I was interested in her situation helped her to feel supported and less alone." Moreover, all of the providers have spoken with women who, after initially declining any counseling or action, decide to seek help later.

Our experience confirms that

support groups are a useful tool.

At first, the women were afraid to

speak about their situations with

others, but after they had done so,

they felt more powerful.

\section{Ongoing Provider Support}

Staff spend a great deal of time ensuring that they are adequately prepared to handle a range of technical and emotional issues. For example, Myrna Flores might organize a brown-bag round-table discussion, the physicians may meet to review protocols, the psychologists may attend an outside workshop, and the guards, as mentioned above, must be trained to assess and handle potential emergencies. Janet Camilo explains that, with new issues emerging and normal staff turnover, "our staff here lives in a constant chain of training."

The psychologists and counselors from all of Profamilia's centers convene every two months to review cases involving violence. The objective of these meetings is to reflect collectively on their experiences, as well as to stan- 
dardize their approach across the clinics. The group agrees on a way to handle a specific type of case, and this becomes future standard practice. Magaly Caram attends some of these case-study discussions, as does Flores. Similarly, at one clinic, all of the providers meet every two months to discuss cases. Staff members do not need to wait for these regular sessions to discuss a difficult case-they can convene a meeting at any point. Two points are always discussed when the cases are analyzed: how the provider dealt with the case and what the best way would be to deal with a similar case in the future.

\section{Profamilia carries out a wide} range of outside policy

activities-from a plan to ensure

that medical residents learn

about gender-based violence to

a research study of femicide

(the murder of women).

\section{Beyond the clinic: Advocacy and Public Education}

Profamilia's involvement with genderbased violence began in the policy arena, when it joined the commission that ultimately designed and promoted Law 24-97. Although the clinics now run a dynamic service program, the agency has also sustained its advocacy activities. As Magaly Caram recalled, from the beginning the violence services had to "parallel advocacy and education across sectors, [that providers had to] work with the police, judges, and the Departments of Public Prosecution, Health, and Justice." Camilo added, "It is no good offering legal counseling if you don't have good options to recommend. To find good options we have had to work on changing the system."

Most of Profamilia's advocacy work is undertaken in partnership with other NGOs or with government agencies. As Flores explained, "In advocacy work, one cannot do anything alone. Alliances must be forged with many different types of institutions." Staff work closely with the Women's Support Nucleus (NAM), an NGO that conducts research on gender-based violence. Among many collaborative efforts, the two organizations coordinate a coalition of NGOs and government agencies called MOVIDA, or Movement for a Life without Violence. Among its activities, MOVIDA conducts group therapy with male abusers. Profamilia also worked with the director of NAM on a study of "femicide" (murder of women) in the country. Other joint efforts between the two organizations are described below.

Profamilia is also active on the National Commission to Fight and Prevent Intrafamilial Violence, an interagency government alliance coordinated by the Ministry of Women. A major policy document 
that emerged from this alliance was the National Strategic Plan for the Prevention and Treatment of Domestic Violence, geared toward strengthening the violence laws and bettering their application.

\section{Safeguarding Law 24-97}

In 1998, in response to pressure from conservative groups, the Dominican Senate voted to weaken Law 24-97. The changes involved deletion of the mention of sexual violence within a relationship, the weakening of the language on incest, and the total elimination of the classification of gender-based violence. Furthermore, the penalties associated with abortion, already illegal under Dominican law were increased. With its allies, Profamilia lobbied intensively against these changes. An ad hoc coalition of NGOs presented alternative language, which Janet Camilo helped to draft. The final outcome of the legislation is still unresolved.

\section{Improving the Treatment of Women Who File a Complaint}

Flores and the director of NAM successfully lobbied officials for funds to construct a new building for comprehensive, high-quality services for women who file a complaint against an aggressor in the city of Santiago. Under one roof the center will house the office of the public prosecutor, forensic doctors, police, lawyers, and psychologists; it will also serve as a training center for these public servants.

The government passed a separate law in 2003 mandating the establishment of women's shelters. In response to a recent request by the Ministry of Women, Profamilia is helping to develop norms and regulations governing the functioning of these shelters for those fleeing violence.

\section{Promoting Awareness in the Health and Legal Sectors}

Profamilia's staff have conducted a number of workshops for health-care and legal professionals. The Health Department now incorporates IPPF/WHR's violencescreening tool in the national guidelines governing the care of victims of family violence. The screening tool is included among the tools suggested for detecting interfamilial violence against women.

Recently, the Profamilia physicians have begun to promote a plan to encourage professors of obstetrics and gynecology to teach their medical residents about gender-based violence. The plan is moving forward with technical assistance from the IPPF regional office and may include a clinical rotation at Profamilia. Profamilia staff have also conducted workshops for law-enforcement agencies, judges, armed-forces personnel, and new public prosecutors and public defenders. These workshops aim to promote better understanding of women's vulnerability to violence, their rights under violence legislation, and the kinds of services they need. They have also provided a venue for Profamilia to explain the importance of accepting psychological reports and photographs as evidence. In one series of workshops, the trainers used legal guides developed during the early years of the initiative for Profamilia providers; the overwhelmingly positive response to these guides led to their publication for a wider audience. Profamilia also worked with NAM to train a group of public prosecutors across the country to become trainers on gender-based violence. The four modules they developed for these workshops focused on femicide; gender, masculinities, and unequal power dynamics in heterosexual relationships; the violence laws and the role of the Department of Public Prosecution; and a review of basic concepts using case studies. 
Profamilia staff followed up the workshops by helping the Department of Public Prosecution develop service protocols for attending to women who file domestic violence complaints. The document, which significantly revamped how offices of the public prosecutor would process cases, was approved in 2002 to much fanfare. The subsequent departure of the top official from office has prevented the protocol from being implemented to date, however.

The impact of these types of trainings always is constrained by institutional culture, lack of follow-up, and turnover of personnel. Janet Camilo explained that, for Profamilia, the effort is a worthwhile one: "You plant a seed continuously, and you succeed little by little. As personnel turns over, you work change through more and more people." Those they train over time become allies and people to whom Profamilia staff can refer clients.

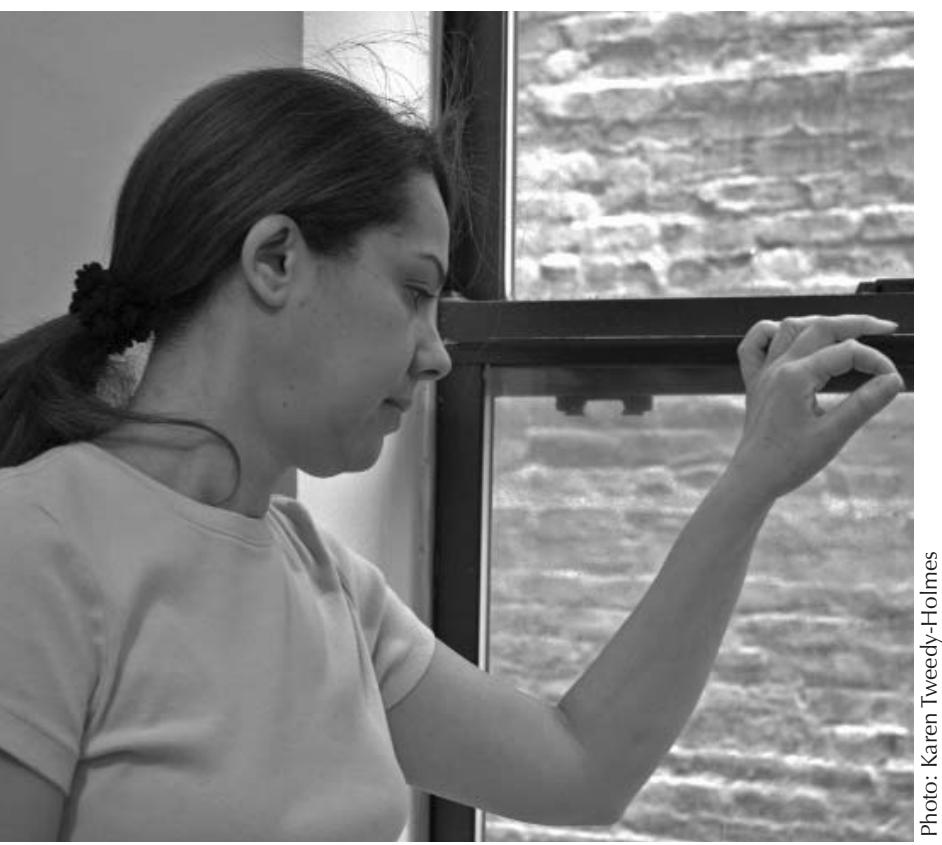

Counselors explain that "You frequently hear people saying that women like to be mistreated, that men are violent because they are men ..." Changing such attitudes is part of Profamilia's broader mission.

\section{Preventing Future Violence}

Profamilia is conscious of the need for changes in community norms to prevent future violence, and staff frequently address groups convened through NGOs or the private sector. For example, in response to a request by a consortium of 15 companies in Santiago's free-trade zone, Profamilia staff give presentations about gender-based violence to employees at all levels, from the doorman to the directors; to date, 12,000 employees have attended these talks. Mariana Santos, a counselor who has conducted more than 40 such workplace talks, explains that traditional gender attitudes emerge during these discussions: "You frequently hear people saying that women like to be mistreated, that men are violent because they are men, that men don't cry, that the man is the head of the family and has the right to make all decisions." The private-sector consortium is also building the capacity of its members to serve as a safe confidantes from whom employees can seek help with violence, and their human resources departments refer women to Profamilia. A number of workers have also requested information about child abuse.

\section{Reaching Young People}

Gender-based violence has become a linchpin of Profamilia's peer-education program. Staff have trained 60 peer educators to speak about such violence in their youth-clinic talks and in their outreach efforts, to handle sensitive discussions and listen effectively, and to make referrals for direct services. Recently, they also commemorated the International Day Against Violence Against Women with a march and demonstration at which Crucita spoke. 


\section{The Media}

Profamilia has long had significant access to the media. Staff members have been interviewed about gender-based violence on television talk shows, on radio call-in programs, and in newspaper articles. As a counselor commented, "Because Profamilia as an institution has played a protagonist role in the issue of gender-based violence, the media call us when they are doing a piece relating to the topic, and we accept their calls. We are always looking for a way to bring the issue into these spaces."

\section{Tools for Health-care Providers in Other Institutions}

In 2003, the IPPF/WHR office and the associations involved in the genderbased violence project collaborated to produce two videos: one (entitled "Basta! The Health Sector Addresses Genderbased Violence") was designed as a training tool for health-care providers. The other (entitled "Basta! Women Say No to Violence") was designed as a general sensitization tool. The former features providers from Profamilia and from PLAFAM, the Venezuelan sister association, who explain how addressing the issue of gender-based violence can improve the quality of health care and generate personal and professional changes. The latter film features more than a dozen clients who describe how the violence in their lives affected their health and well-being, talk about the complexities they encountered in leaving their violent relationships, and share the steps they took to overcome their violent situations.

More recently, IPPF/WHR published a manual for other health-care service organizations, "Improving the Healthsector Response to Gender-based Violence: A Resource Manual for Healthcare Professionals in Developing Coun- tries" (Bott et al. 2004). The manual contains comprehensive program guidelines for an overall institutional response to gender-based violence. The recommen-

In 2004, the Board of Directors

approved a strong institutional

policy on sexual harassment.

According to Magaly Caram, "This

project changed the organization.

In institutional terms, it converted

us from a family planning

organization to a sexual and

reproductive health organization

that truly serves women."

dations are based on lessons learned from the three associations' experiences.

\section{What the Project Means for Profamilia}

Although the original project grant terminated several years ago, the gender-based violence work has continued to progress at Profamilia. (Sustaining funding and a sufficient client load to retain the services of multiple staff lawyers is the one area under financial constraint. Profamilia is exploring the possibility of using lawschool interns as well as lawyers to provide legal services.) Moreover, working on violence has proved to be an effective entry point for incorporating a gender and rights perspective into the association's work. For example, in 2004, the Board of Directors approved a strong institutional policy on sexual harassment.

According to Magaly Caram, "This project changed the organization. In 
institutional terms, it converted us from a family planning organization to a sexual and reproductive health organization that truly serves women. This project provoked a radical change in our actions."

Gender-based violence is a neglected public health problem throughout the world. The Profamilia experience provides a guidepost for how family planning and other health programs can respond. giovanni, Strategic Advisor of Programs, says, "The clinic administrators, when putting together their budgets, defend the employment of the psychologists, even though this is an expense for the clinic." Clinic manager Jose Raphael concurred: "Sometimes I think how paradoxical this all is. I thought that involving the providers in this process was going to produce a lot of resistance. But on the contrary, the involvement has motivated everyone."

Dr. Alvarez summed up the sentiments of many, saying, "In this country very sad things have happened. . . . There are times when we cannot protect women. . .. We learned at the beginning that we were going to face a lot of frustrations, that this is a path full of thorns, and that we can't protect women all the time. But this work is worth continuing. We cannot achieve everything, but I believe we are achieving something."

\section{Lessons Learned}

- Women are willing to talk to a supportive provider about their experience of genderbased violence, although some may wait to disclose information for some time after the initial screening visit. Even for women who choose not to seek further help, engaging a provider's respectful attention is a valuable experience.

- Routine screening of all clients for experience of gender-based violence by means of standardized questionnaire eases providers' and clients' approach to this topic.

- Improving the health-service response to gender-based violence virtually always requires investments in clinic infrastructure, protocols and policies, referral systems, and (where possible) hiring of in-house mental health and legal professionals.

- Medical personnel who are hesitant to become involved in cases of domestic violence may be more open to a scientific approach to the issue. Detailed interview forms designed to guide their interactions with clients may also increase their comfort levels.

- Screening women for their experience of violence can enhance physicians' diagnostic skills and sense of professional satisfaction.

- Support groups can provide a sense of solidarity and empowerment for women and girls suffering from gender-based violence.

- The issue of gender-based violence radiates beyond the health-care sector. Broad alliances must be established both for service referrals and for advocacy aimed at changing norms and legislation. 


\section{References}

Bott S., A. Guedes, and A. Guezmes. Forthcoming. "The health service response to sexual coercion/violence: Lessons from IPPF/WHR member associations in Latin America." In Sex Without Consent: Young People in Developing Countries. Eds. S. Jejeebhoy, S. Iqbal and T. Shyam. London: Zed.

Bott S., A. Guedes, A. Guezmes, and C. Claramunt. 2004. "Improving the health sector response to gender-based violence: A resource manual for health care professionals in developing countries." International Planned Parenthood Federation, Western Hemisphere Region. $<$ http://www.ippfwhr.org/publications/ download/monographs/GBV_Manual_E. pdf $>$. Accessed October 2005.

Center for Social and Demographic Studies (CESDEM) et al. 2003. Dominican Republic Demographic and Health Survey-2002. Santo Domingo, Dominican Republic: ORC Macro/MEASURE DHS+.

CONAPOFA (National Council of Population and Family) and Institute for Resource Development (IRD)/Westinghouse. 1987. República Dominicana Encuesta Demográfica y de Salud-1986 (DHS). Santo Domingo, Dominican Republic: Editora Alpha y Omega.

Guedes A., S. Bott, and Y. Cuca. 2002 "Integrating systematic screening for genderbased violence into sexual and reproductive health services: Results of a baseline study by the International Planned Parenthood Federation/Western Hemisphere Region." International Journal of Obstetrics and Gynaecology 78(Supplement 1): S57-S63.

Guedes A., S. Bott, A. Guezmes, and J. Helzner. 2002. "Gender-based violence, human rights, and the health sector: Lessons from Latin America." Health and Human Rights 6(1): 177-193.

Guezmes, Ana. 2002. "Sistematización del Proyecto de IPPF: Proyecto para Combatir la Violencia Basada en Genero de America Latina." New York: IPPF/WHR. Unpublished.
Guezmes, Ana and Lita Vargas. 2003. "Informe final de la comparación entre línea basal y línea de salida en INPPARES, PLAFAM, y PROFAMILIA." New York: IPPF/WHR. Unpublished.

Helzner, Judith. 2002. "Transforming family planning services in the Latin American and Caribbean region." Studies in Family Planning 33(1): 49-60.

Kishor, Sunita and Kiersten Johnson. 2004. Profiling Domestic Violence-A MultiCountry Study. Calverton, MD: ORC Macro.

Moore, Kirsten and Judith F. Helzer. 1996. What's Sex Got to Do with It? Challenges for Incorporating Sexuality into Family Planning Programs. New York: Population Council and IPPF/WHR. <http://www. popcouncil.org/pdfs/whatssex.pdf $>$. Accessed 2 June 2006.

Ortiz-Ortega, Adriana and Judith Helzner. 2003. "Opening windows to gender: A case study in a major international population agency." Social Politics: International Studies in Gender, State and Society 10(1): 129-152.

Pan-American Health Organization (PAHO). 2001. "Country Health Profile: Dominican Republic." <http://www.paho.org/ English/SHA/prfldor.htm>. Accessed December 2004.

UNAIDS (Joint United Nations Programme on HIV/AIDS). 2002a. "Epidemiological fact sheets on HIV/AIDS and sexually transmitted diseases: 2002 Update, Dominican Republic." <www.unaids.org $>$. Accessed 10 October 2003.

___ 2003. "Dominican Republic." $<$ http://www.unaids.org/EN/Geographica I+Area/by+country/dominican+republic.asp>. Accessed 4 December 2003.

UNFPA (United Nations Population Fund). 2004. "Dominican Republic Country Profile." <http://www.unfpa.org/profile/ dominicanrepublic.cfm>. Accessed December 2004.

World Bank. 2003. "Dominican Republic at a glance." Washington, DC: World Bank Group. <http://www.worldbank.org/data/ countrydata/aag/dom_aag.pdf>. Accessed December 2004. 


\section{Resumen en Español}

A mediados de los años 90, Profamiliala asociación miembro de la Federación Internacional de Planificación de la Familia (IPPF) en la República Dominicanainstaló un programa contra violencia de género (VBG). Incluyó un proceso de tamizaje entre sus clientes (mujeres y jóvenes) sobre experiencia con VBG, servicios psicólogos y legales, y actividades para cambiar normas y leyes. La oficina regional de IPPF prestó apoyo a Profamilia y a otras dos Asociaciones Afiliadas para ejecutar este proyecto.

En primer lugar, la Junta Directiva amplió su misión para incluir la abolición de VBG. Profamilia contrató a una coordinadora de proyecto, psicólogas y una abogada. Entre las actividades iniciales se incluyó la capacitación del personal; insonorización de salas de consulta; y diseño de protocolos, sistemas de referencia y cuestionarios para el tamizaje sobre VBG.

En la sala de espera se han colgado afiches sobre VBG. Durante la consulta, el doctor explica que vivir libre de violencia es el camino hacia la salud. Si la paciente acepta someterse al proceso de tamizaje, el doctor le pregunta sobre su historial de violencia (emocional, psíquica y sexual, incluyendo el incesto) y evalúa su riesgo actual.

Las usuarias que declaren sufrir VBG pueden hablar con la psicóloga. Dado que muchas mujeres no están en condiciones de abandonar una relación abusiva, los consejos a menudo se centran en ayudar a las mujeres a crear una red de apoyo y un plan de seguridad de emergencia. Para aquellas que deseen denunciar cargos legales, el personal le ofrece asesoría inicial y la remite a un fiscal conocido.

\section{Resultados}

Profamilia cuestiona a más de 16.000 pacientes sobre VBG al año. Un 14 por ciento de éstas reporta abusos pasados o actuales (76 por ciento psicológicos, 46 por ciento físicos, 30 por ciento sexuales y 27 por ciento abuso sexual durante la niñez). Un tercio desea seguir recibiendo consejos; un 2 por ciento inicia acciones legales.
Una evaluación desveló que las pacientes valoran la oportunidad de hablar sobre la violencia en sus vidas. Entre quienes no reportan violencia, 91 por ciento valoró el proceso de tamijazje/detección. Los médicos experimentaron una mejora drástica en sus conocimientos y en su grado de satisfacción profesional. Informaron asimismo que carecía de fundamento su preocupación inicial sobre el incremento de trabajo que iba a representar el examen y el impacto sobre su salario.

Los retos a afrontar incluyen: la dificultad de convencer a algunas parejas varones o a familiares para que abandonen la sala durante el examen; garantizar que otros empleados no interrumpen durante la consulta; aceptar que algunas víctimas de abusos prefieren no hacer nada; capacitar al personal de seguridad a interactuar con los maridos agresivos; facilitar capacitación y apoyo continuo al personal; y mantener recursos para especialistas legales.

\section{Actividades de promoción y diseño de políticas}

Incluso antes de que Profamilia iniciara el tamizaje sobre violencia, la organización había presionado a favor de una ley VBG fuerte. Una vez aprobada la ley, Profamilia continuó trabajando con otros organismos y con el gobierno para desarrollar la ley, mejorar el tratamiento de las mujeres denunciantes y capacitar a profesionales de salud y legales sobre VBG. Sus actividades de prevención de violencia futura se realizaron por medio de educación comunitaria, los medios y programas de juventud.

Algunas de las lecciones aprendidas: 1) Las mujeres están dispuestas a hablar con proveedores sobre la violencia en sus vidas; 2) El examen inicial debe convertirse en rutina y basarse en un cuestionario estándar; 3) El personal médico puede estar mejor dispuesto a aplicar un enfoque científico a este tema; 4) Los grupos de apoyo pueden empoderar a las participantes; 5) Se requieren alianzas más allá del sector salud para tratar el tema de la violencia de género. 


\section{Résumé en Français}

Au milieu des années 90, Profamilia [l'association dominicaine affiliée à la Fédération internationale pour la planification familiale (IPPF)] a commencé à fournir des services aux femmes et aux filles victimes de violence de genre, et à mener un plaidoyer en vue de la modification des normes et des lois. Le bureau régional de I'IPPF a fourni un appui à Profamilia ainsi qu'à deux autres associations affiliées pour réaliser ce projet.

Tout d'abord, le conseil d'administration a élargi ses missions afin d'y inclure I'élimination de la violence de genre. Ensuite, Profamilia a engagé un coordonnateur de projet, des psychologues et un avocat. Parmi d'autres activités initiales figuraient la formation du personnel, I'insonorisation des salles de counseling ainsi que l'élaboration de protocoles, de mécanismes d'orientation des clientes vers d'autres services, et d'un questionnaire de dépistage.

Des affiches sur la violence de genre sont placardées dans la salle d'attente. Pendant la consultation, le médecin explique à la cliente que l'absence de violence fait partie de la santé. Si la cliente consent à subir l'examen de dépistage unique, le médecin I'interroge sur ses antécédents en matière de violence (émotionnelle, physique et sexuelle-y compris l'inceste) et évalue les risques qu'elle encourt actuellement.

Les clientes qui déclarent être victimes de violence de genre peuvent en parler à un psychologue. De nombreuses femmes n'étant pas prêtes à mettre fin à une relation de maltraitance, le counseling s'attache souvent à aider les femmes à élaborer un réseau de soutien ainsi qu'un plan de sécurité en cas d'urgence. Pour les femmes qui désirent intenter un procès à leur partenaire, le personnel fournit les premiers éléments d'approche, et les oriente vers un procureur qu'il connaît bien.

\section{Résultats}

Profamilia examine les cas de plus de 16 000 clientes par an. Environ 14 pour cent des femmes signalent des mauvais traitements dans le passé ou au présent (76 pour cent d'abus psychologiques, 46 pour cent d'abus physiques, 30 pour cent d'abus sexuels et 27 pour cent d'abus sexuels sur des enfants). Deux pour cent des clientes intentent une action en justice.
Une évaluation a révélé que les clientes appréciaient de pouvoir parler de la violence. Quatre-vingt-onze pour cent des clientes ne $s^{\prime}$ étant pas plaintes de violence étaient d'accord que le dépistage était une opération essentielle. Les connaissances des médecins ont considérablement augmenté, de même que leur satisfaction professionnelle. En outre, ils ont déclaré que leur souci initial à l'idée que le dépistage augmenterait leur charge de travail, et réduirait leur salaire, s'était révélé sans fondement.

Les défis comprenaient la difficulté de persuader les partenaires masculins ou les membres de la famille de quitter la salle avant le dépistage, d'empêcher les autres membres du personnel d'entrer dans la salle de consultation, d'accepter que certaines des femmes maltraitées choisissent de ne pas intenter d'action, de former le personnel de sécurité à maîtriser les maris furieux, de fournir la formation continue et du soutien au personnel, ainsi que des fonds pour le personnel juridique.

\section{Activités de plaidoyer pour des changements de politiques}

Avant même d'entamer le dépistage de la violence, les responsables de Profamilia avaient commencé à plaider en faveur $d^{\prime}$ une loi nationale forte en matière de violence de genre. Après I'adoption de la loi, ils ont continué à collaborer avec d'autres organisations ainsi que le gouvernement pour faire appliquer la loi, améliorer le traitement des femmes ayant déposé une plainte et former les professionnels juridiques et de santé en matière de violence de genre. Ils préviennent également d'autres actes de violence par l'intermédiaire de l'éducation communautaire, des médias et des programmes en faveur de la jeunesse.

Certaines des leçons tirées sont les suivantes : 1) Les femmes sont prêtes à parler à un prestataire de la violence dans leur vie ; 2) le dépistage doit être systématique et standardisé ; 3) il se peut que le personnel médical soit plus ouvert à une approche scientifique du problème ; 4) les groupes de soutien peuvent habiliter les participants, et 5) des alliances au-delà du secteur sanitaire sont nécessaires pour résoudre le problème de la violence de genre. 


\section{About the Authors}

Claudia García-Moreno is the Coordinator of the Department of Gender, Women and Health at the World Health Organization.

Rachel Goldberg is a Monitoring and Evaluation Associate for the ACQUIRE Project/EngenderHealth.

\section{Profamilia}

Calle Socorro Sánchez \#160, Gazcue Santo Domingo, República Dominicana Apartado Postal 1053 Tel. (809) 689-0141; Fax. (809) 686-8276 info@profamilia.org.do; www.profamilia.org.do

\section{Acknowledgments}

The author would like to extend special thanks to Myrna Flores, Alessandra Guedes, Sarah Bott, and Judith Helzner for making available background materials on the program, for their willingness to answer questions, and for their review of draft manuscripts. She also extends her gratitude to all the staff, clients, and survivors of genderbased violence that she interviewed for their time and for their candor.

We invite your comments on Quality/Calidad/Qualité. If you would like to be included on our mailing list, please send an e-mail to: qcq@popcouncil.org. Most past editions are available online at $<w w w$.popcouncil.org/publications/qcq/default.htm $>$. Single or multiple print copies of past editions may be ordered by e-mail.

No. 1 Celebrating Mother and Child on the Fortieth Day: The Sfax Tunisia Postpartum Program, 1989. (E)

No. 2 Man/Hombre/Homme: Meeting Male Reproductive Health Care Needs in Latin America, 1990. (E,S)

No. 3 The Bangladesh Women's Health Coalition, 1991. (E)

No. 4 By and For Women: Involving Women in the Development of Reproductive Health Care Materials, 1992. (E,S)

No. 5 Gente Joven/Young People: A Dialogue on Sexuality with Adolescents in Mexico, 1993. (E,S)

No. 6 The Coletivo: A Feminist Sexuality and Health Collective in Brazil, 1995. (E,P,S)

No. 7 Doing More with Less: The Marie Stopes Clinics of Sierra Leone, 1995. (E)

No. 8 Introducing Sexuality within Family Planning: Three Positive Experiences from Latin America and the Caribbean, 1997. (E,S)

No. 9 Using COPE to Improve Quality of Care: The Experience of the Family Planning Association of Kenya, 1998. (E,S)

No. 10 Alone You Are Nobody, Together We Float: The Manuela Ramos Movement, 2000. (E,S)

No. 11 From Patna to Paris: Providing Safe and Humane Abortion, 2001. (E)

No. 12 Universal Sexuality Education in Mongolia: Educating Today to Protect Tomorrow, 2002. (E)

No. 13 What about Us? Bringing Infertility into Reproductive Health Care, 2002. (E)

No. 14 "My Father Didn't Think This Way": Nigerian Boys Contemplate Gender Equality, 2003. (E,F)

No. 15 Linking Reproductive Health to Social Power: Community Health Workers in Belize and Pakistan, 2004. (E)

No. 16 Healing Wounds, Instilling Hope: The Tanzanian Partnership Against Obstetric Fistula, 2004. $(\mathrm{E}, \mathrm{F}, \mathrm{Sw})$

No. 17 In Our Own Hands: SWAA-Ghana Champions the Female Condom, 2006. (E) 
Quality/Calidad/Qualité, 